\title{
SYSTEM-WIDE SIGNIFICANCE OF PREDATION ON JUVENILE SALMONIDS IN THE COLUMBIA AND SNAKE RIVER RESERVOIRS
}

\author{
Annual Report of Research \\ 1991 \\ Prepared by \\ R. S. Shively \\ R. A. Tabor \\ R. D. Nelle \\ D. B. Jepsen \\ J. H. Petersen \\ S. T. Sauter \\ T. P. Poe \\ U. S. Fish and Wildlife Service \\ National Fishery Research Center \\ Columbia River Field Station

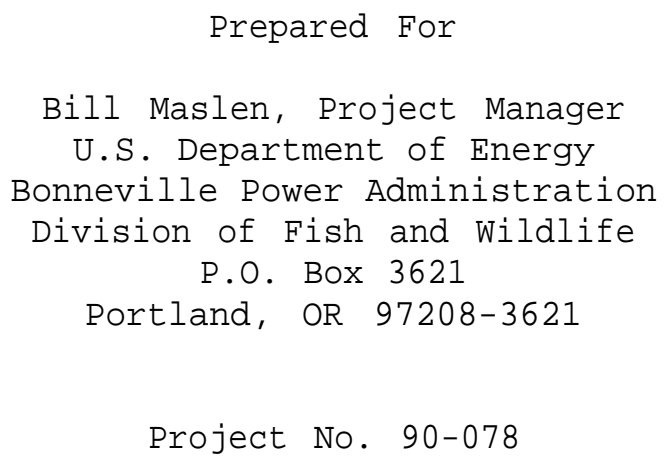


TABLE OF CONTENTS

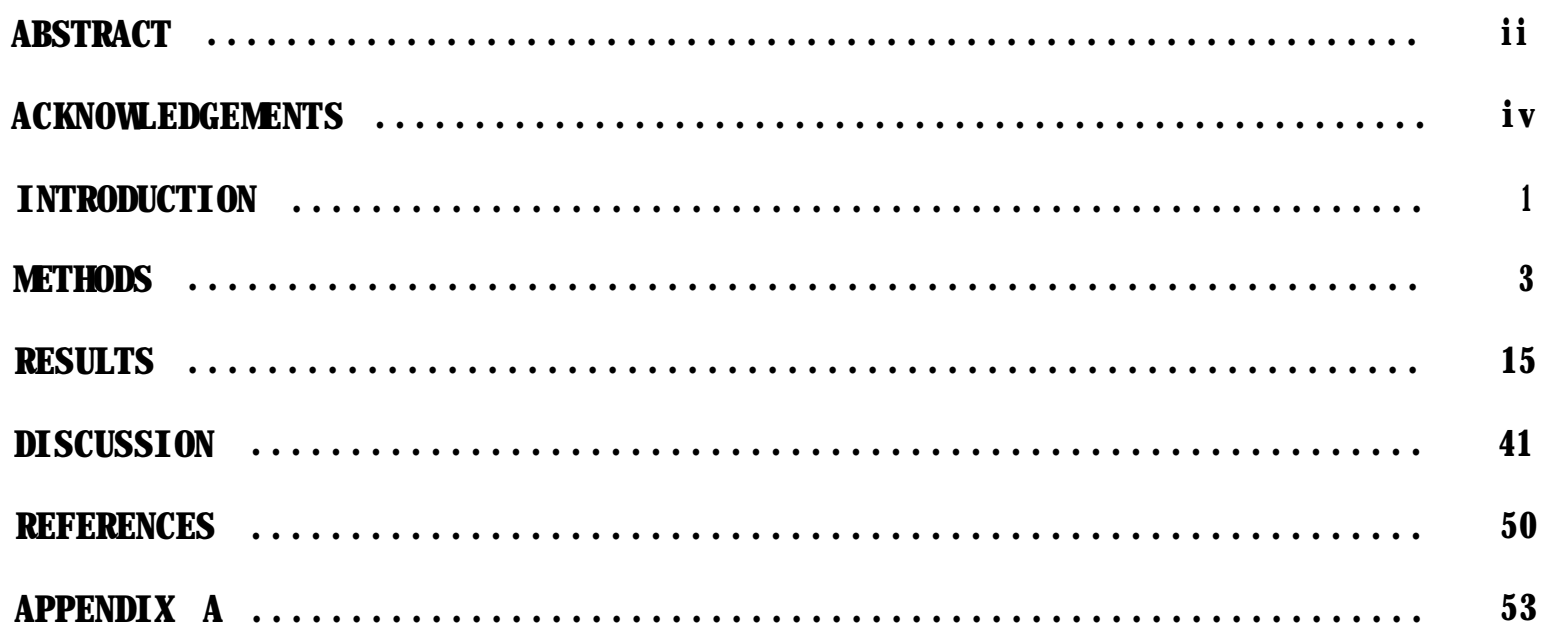


We i ndexed consumpti on rates of northern squauf i sh ( Ptvchochei I us oresonensi s) preyi ng upon j uveni I e sal moni ds i n four I ower Snake Ri ver reservoi rs (Ice Harbor, Lower Mnumental, Lïttle Goose, and Lower Grani te) and J ohn Day Reservoi r, Col unbia Ri ver, i n 1991. We capt ured a total of 2118 northern squauf i sh at Snake Ri ver I ocati ons from Apri I to June and 297 i n J ohn Day Reservoi $r$ during My and Jul y. Catches of northern squaufi sh were hi ghest withi $\mathrm{n}$ the boat restricted zone (BRZ) of dam tail race areas. Stonach contents were al so col I ected from snal I mouth bass (Mcropter us dol oni eui ), channel catfish (I ctal uris ounctatus), and wal I eye (Stizostedi on vi treum).

A total of 1408 northern squauf $i$ sh di gesti ve tracts were anal yzed and the overal I di et ( $\%$ wei ght) was dom nat ed by fi sh and crustaceans ( $55 \%$ and $26 \%$ respecti vel y). On average, northern squauf $\mathrm{i}$ sh contai ned 0.63 salmonids. fish ${ }^{-1}$, and northern squauf i sh col lected i n BRZs cont ai ned si gni fi cantl y more sal moni ds ( 0.83 salmonids. ish $\left.^{-1}\right)$ than those col l ected in non- restricted zones ( 0.53 salmonids.fish $\left.{ }^{-1} ; \mathrm{P}<0.001\right)$. We al so anal yzed stomach contents of 1145 smal I mouth bass. Crustaceans (pri marily crayfish) dom nated the di ets of smal I nouth bass ( $64 \%$ fol l owed by fi sh $(27 \%)$. Overal I, the consumpti on rate of $\mathbf{j}$ uveni I e sal noni ds by smal I mouth bass was I ow ( 0.01 salmonids $\left.\cdot \mathrm{fish}^{-1} \cdot \mathrm{day^{-1 }}\right)$.

The northern squauf i sh consumpti on i ndex (CI) at Snake Ri ver I ocati ons ranged from zero at al I mid-reservoi $r$ locations to 1.2 at Lower Granite forebay. In J ohn Day Reservoi r, Cl val ues ranged from 0.5 to 1.9 in May and from 0.9 to 3.0 i $\mathbf{~ J u l y . ~ C o n s u m p t i ~ o n ~ i ~ n d e x ~ v a l ~ u e s ~ w e r e ~ h i ~ g h e s t ~ i ~} \mathbf{n}$ forebay and tai I race areas, and were sl i ghtl y hi gher i n BRZs than i n non-restricted zones. Efforts to conduct $C$ sampl ing duri ng hi gh j uveni l e sal moni d densi ti es were 
successful at most I ocations except at Lower Mbnumental Dam Low water temperat ures at Snake Ri ver I ocati ons (range 6-13" C) my have contri buted to the I ow Cl val ues. Mean C val ues were I ower in the Snake Ri ver I ocati ons compared to Col unbi a Ri ver l ocati ons fromthe spring sampl ing peri od when water temperat ures and species of sal moni ds mi grati ng are si milar ( $\mathrm{Cl}=\mathbf{0} \mathbf{5}$ and 1. 3, respecti vel y).

Wbrk conti nued on a northern squauf i sh bi oenerget i cs i ndex to compl ement the $\mathrm{Cl}$. Fi sh in two age-groups, $\varangle$ and 6 yrs, showed the I argest percent uei ght change duri ing the grouth season ( $36 \%$ and $24 \%$ respecti vel y), whi I e fi sh i $n$ ol der age-groups di spl ayed no si gni fi cant seasonal grouth. Anal ysi s of age and grouth i nf or nati on i ndi cated that rel ati vel y I arge sample si zes of aged northern squaufi sh woul d be needed to detect snal l changes in grouth. An al ternati ve grouth approach exami ni ng changes i n nean predat or uei ght di stributi ons over the growing season was al so expl ored.

The $\mathrm{Cl}$ data wi I be i ntegrated wi th predat or abundance i ndex data esti mated by Oregon Department of Fi sh and Vil dl i fe to deri ve an i ndex of j uveni I e sal moni d predati on by northern squauf i sh i n Snake Ri ver reservoi rs. A so, work wi I conti nue on a bi oenergeti cs nodel to be used i n conbi nation with the $\mathrm{Cl}$. 


\section{ACKNOULEDGEMENTS}

We grateful ly acknow edge Bill Nel son, Al ec Mul e, Steve Vigg, and Craig Tuss for thei $r$ hel pful revi ew coments on an earlier draft of this report. Sampl ing coordi nation was facilitated by the Fi sh Passage Center, particularly Margaret Filardo, whom we thank. We al so thank Bill Masl en, the Bonneville Power Admini strati on contract officer, for his assi stance during the study. 


\section{NTRODUCTI ON}

The U. S. Fi sh and Vil dl ife Servi ce (FVS) and the Oregon Department of Fi sh and Willife (ODFW recently completed a six year study to determine the si gni fi cance of predati on on $\mathrm{j}$ uveni l e sal moni ds i $n$ John Day Reservoi $r$ (Poe and Ri eman 1988). Esti mates of $\mathrm{j}$ uveni I e sal moni d I osses to predat ors i ndi cat ed that predation may account for the maj ority of previ ously unexpl ai ned I osses of j uveni I e sal moni ds i n J ohn Day Reservoi r ( Ri enan et al . 1991). Conti nui ng need for predation research has been desi gnated as high priority by several regi onal comit tees and agenci es i ncl udi ng: (1) the Nort hwest Power PI anni ng Counci I (section 403(d) (1) of the 1987 Col unbi a Ri ver Basi n Fi sh and Vil dl i fe Program and in Septenber 1991 proposed anendments to this program); (2) the Whter Budget Eval uati on - Reservoi r Mrtality Techni cal Wbrk Group (mi nutes of January 27, 1989 neeti ng) ; and (3) the 1989 Predat or-Prey Mbdel ing Wbrkshop ( Fi ckei sen et al., 1990).

A though predati on on $\mathrm{j}$ uveni l e sal moni ds was si gni fi cant i n John Day Reservoi $r$, we do not know the rel ative significance of predation as a nortal ity factor in other Col unbi a and Snake river reservoirs. Because predati on managenent is an ongoi ng program ( $N$ gro 1990), we al so need to: (1) establish basel ine data on predator abundance and consumption rates in other reservoi rs to eval uate the effectiveness of predation management actions; (2) determine where predati on management actions shoul d be i mplenented; and (3) f urther devel op and refine predation model s to hel $p$ eval uate predation management and to predi ct cumul at i ve i mpacts of predat ors on $\mathbf{j}$ uveni I e sal noni $d$ survi val throughout the system

In 1989 a col I aborati ve study of the FWS and CDFW was i ni ti ated to 
devel op a predati on index to esti mate the rel at $i$ ve magni tude of $j$ uveni l e sal noni d I osses to predators in reservoi rs throughout the Col unbi a Ri ver Basi n. Devel opnent of the i ndex was compl et ed in 1990 and det ai l ed descriptions of the analytical, field, and I aboratory techniques for a consumpti on index for northern squaufi sh (Ptvchochei I us or eqonensi s) may be found in Petersen et al. (1990); corresponding methods for abundance indexing may be found in Vigg and Burley (1990).

In 1990 the consumpti on of juvenile sal monids by predators, primarily northern squaufi sh, were i ndexed in four I over Col unbi a Ri ver reservoi rs (Bonneville, The Dal Ies, John Day, and MtNary) and resul ts are reported in Petersen et al. (1991). Thi s report presents the resul ts of indexing northern squauf $i$ sh consumpti on rates upon out-migrating $j$ uveni le sal noni ds in four reservoi rs in the I ower Snake Ri ver and John Day Reservoi $r$ of the Col unbia Ri ver duri ng 1991. 


\section{METHODS}

\section{Fi el d Methods}

Fi el d sampling in 1991 was compl eted wi thi $\mathbf{n}$ the Snake Ri ver at 14 I ocations from Ice Harbor Dam forebay to about 250 meters above the conf I uence of the Snake and Grande Ronde rivers (Fi gure 1, Table 1). Sampling was al so conducted in the I ower porti on of the Cl earuater Ri ver near the city of Lewiston, Idaho. A so, J ohn Day Reservoi $r$ on the Col unbi a Ri ver was sampl ed during the spring ( May) and sumer ( $\mathrm{J}$ ul y) out-migrati on of $\mathbf{j}$ uveni I e sal moni ds to provi de data to account for inter-annual trends (Petersen et al. 1991; Fi gure 2). Ti ming of sampl ing l ocati on? was desi gned to coi nci de wi th maj or hat chery rel eases and i ncreased j uveni l e sal noni d abundance at hydroel ectric dans.

For each reservoi $r$, the naming and sampling of l ocati ons foll owed the methodol ogy of Petersen et al. (1991). To assi st interpretation of resul ts, a typical hydro-electric facility is shown in Figure 3 that displays the positioning of transects withi $\mathrm{n}$ tai I race and forebay boat restricted zones (BRZs).

Dam or project, operati ons were adj usted to al l ow sampl ing wi thi $n$ the BRZs and around i ce trash sl ui ceways, spi I l gates, and powerhouse outf I ous. Sampling was conducted i medi atel y after project operati on change, ther ef ore gut contents of capt ured predators should reflect condi ti ons of typical proj ect operati on.

Tho 18-f oot Smith Root' el ectrof i shing boats were used to capt ure

\footnotetext{
'Mention of brand name does not constitute endorsement by the U.S. Government.
} 


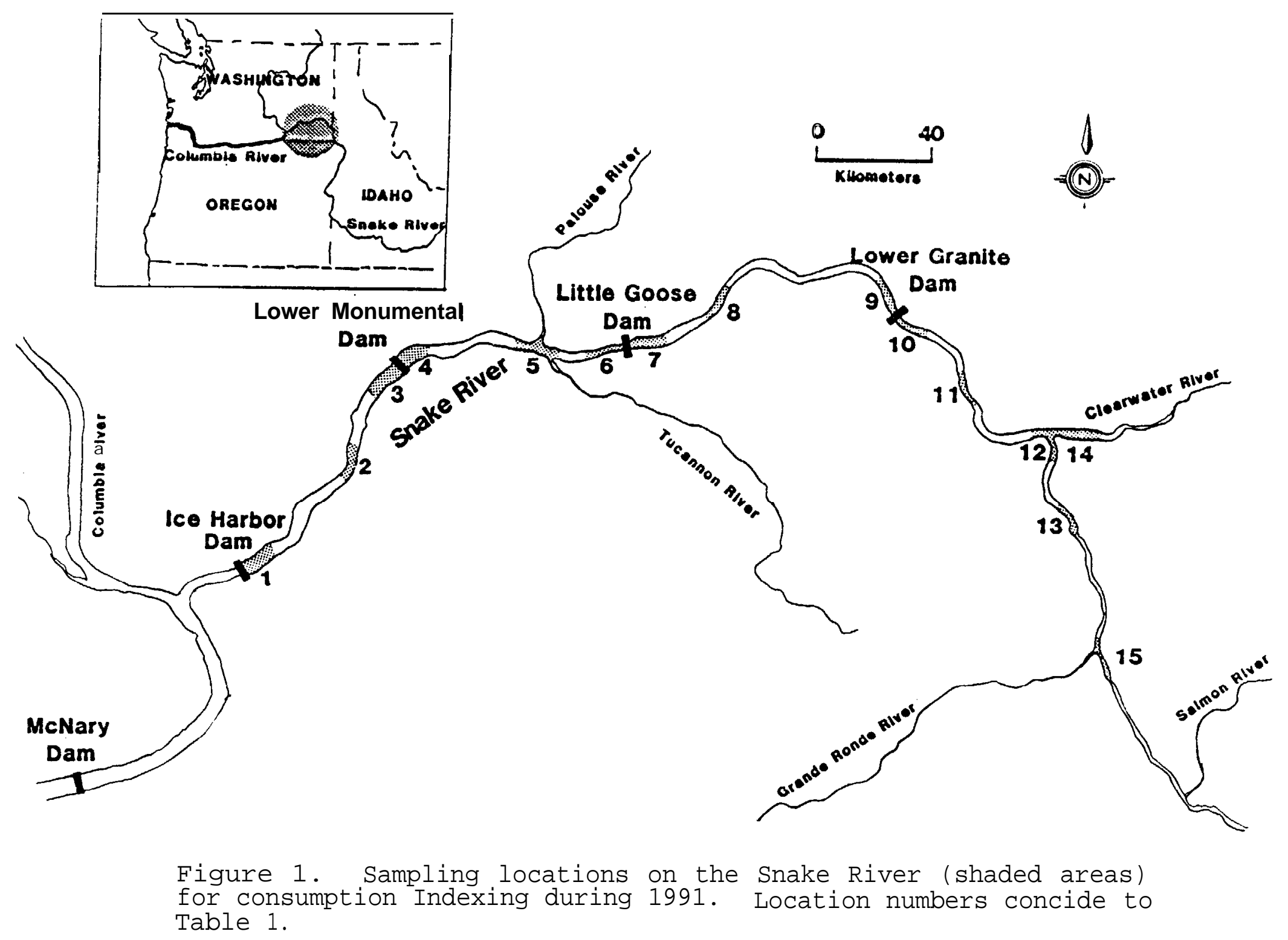


Tabl e 1. Sampling l ocati ons and dates for northern squaufi sh consumpti on i ndexi ng duri ng 1991. Fb=For ebay, $\mathbf{M r}=\mathbf{M} \mathbf{d}$ - $r$ eservoi $\mathbf{r}, \mathbf{T r}=\mathrm{Tai} \mathbf{I}$ race, Up=Upper reservoi $r$.

\section{RESERVO R}

Locati on
R VER

KILOMETER

\section{DATES SAMPLED}

Snake Ri ver

ICE HARBOR

1. Ice Harbor Fb

2. Ice Harbor $\mathbf{M r}$

3. Lower Monumental Tr

\section{LOVER MONUMENTAL}

4. Lower Monumental Fb

5. Lower Monunental Mr

6. Little Coose Tr

\section{TTLE GOOSE}

7. Little Coose $\mathrm{Fb}$

8. Little Goose Mr

9. Lower Grani te Tr

\section{LOVER GRAN TE}

I Q. Lower Grani te Fb

II. Lower Granite Mr

12.Lower Grani te Up

13.Asotin

14.Clearwater $\mathrm{R}$.

\section{FREEFLOW NG RI VER}

15. Roger sburg

Col unbi a Ri ver

\section{J OHN DAY}

16.John Day Fb

17.John Day Mr

18.McNary Tr
16-23

28-39

60-67

67-72

92-100

105- 112

$112-120$

$128-136$

165-172

172-180

$185-196$

219-228

229-238

0-6

268-276

347-353

387-395

459-468
$5 / 14-5 / 15$

$5 / 9-5 / 10$

$5 / 9-5 / 10$

$5 / 30-5 / 31$

$5 / 28-5 / 29$

$5 / 31-6 / 1$

$5 / 7-5 / 8$

$5 / 7-5 / 8$

5/ 29- 5/ 30

$5 / 2-5 / 3$

$5 / 23-5 / 24$

$5 / 23-5 / 24$

$5 / 2-5 / 3 \quad 5 / 21-5 / 22$

$4 / 30-5 / 1 \quad 5 / 21-5 / 22$

$4 / 18-4 / 19 \quad 4 / 27-4 / 29$

$4 / 16-4 / 17 \quad 4 / 26,4 / 28$

$4 / 11-4 / 12 \quad 4 / 25-4 / 26$

$4 / 3,4 / 5 \quad 4 / 10,4 / 12$

$4 / 9-4 / 10 \quad 4 / 23-4 / 24$

$4 / 2,4 / 4 \quad 4 / 9,4 / 11$

$4 / 5-4 / 6 \quad 4 / 16,4 / 19$ $\begin{array}{ll}5 / 16-5 / 17 & 7 / 11-7 / 12 \\ 5 / 15,5 / 21 & 7 / 11-7 / 12 \\ 5 / 16-5 / 17 & 7 / 9-7 / 10\end{array}$ 


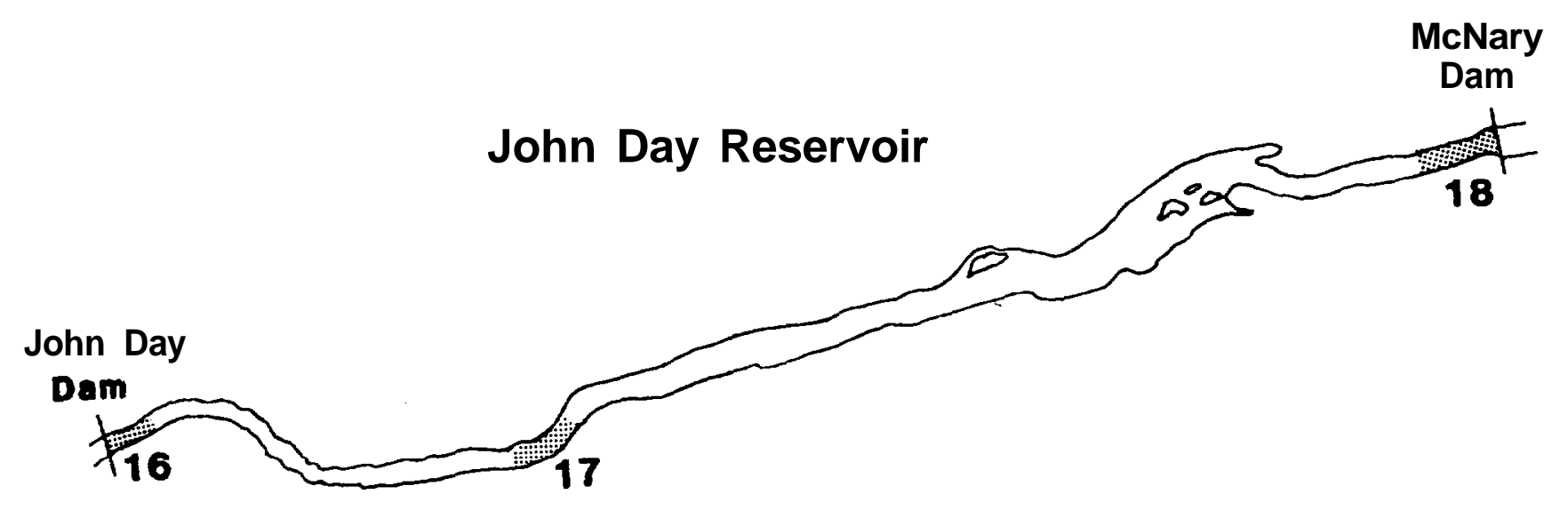

Figure 2. Sampling locations for John Day Reservoir during 1991 northern squawfish Consumption Indexing. 


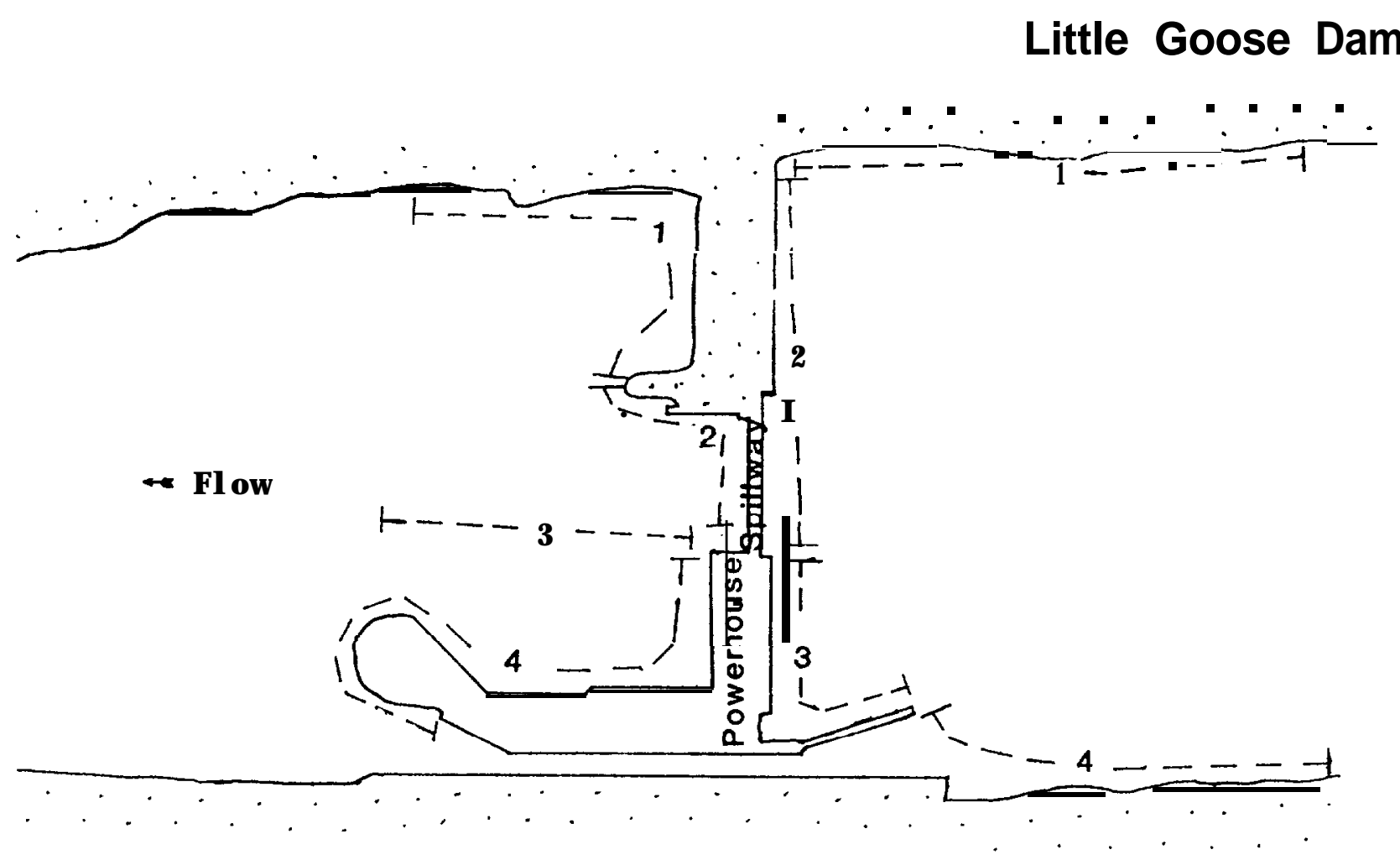

Figure 3. An example of typical sample locations within the Boat Restricted Zone (BRZ) of a dam. 
predators. Transects were el ectrof $i$ shed for 15 mi nut es and the fi rst si $x$ transects each day were chosen at random In forebay and tai I race I ocati ons, two of the six random transects were from BRZs. Addi ti onal, di screti onary transects uere sampled to maxi mize catch of northern squaufi sh. A mi mim target catch of 30 northern squauf $i$ sh per day at each I ocati on was establ i shed (Petersen et al. 1990); however, around dans the mi nim target catch was spl it i nto tuo units; 15 per day in the BRZ and 15 per day outsi de the BRZ. Sampl ing commenced $90 \mathrm{~min}$ before sunri se at al I locations. Target predators were northern squaufi sh, snal I nouth bass (Micropterus dol om eui), channel catfish (I ctal urus punctatus), and wal l eye (Stizostedion vi treum). Nbrthern squauf ish were killed soon after capt ure with a lethal dose of tricai ne net hanesul fonate (MS-222) to prevent regurgi tati on of di gesti ve tract contents. Other predators were retai ned al ive in I i vewel Is with aerated and ci rculating water until processing of di gestive tract contents could be compl et ed.

Fi el d data col l ected on northern squauf i sh i ncl uded: fork I ength (FL, nearest $\mathrm{mm}$ ), wei ght (nearest 5 or $10 \mathrm{~g}$, dependi ng upon fi sh si ze), sex, and stage of maturity. Scal es were removed for age and grouth i nf or nation. Di gesti ve tract contents from northern squaufi sh over $200 \mathrm{~mm}$ FL were taken by pi nching of the anterior and posterior portions of the digestive tract, then removing the enti re gut and placing it in a plastic bag. This techni que was i ncorporated to faci litate the col l ecti on of coded-wi re-tags (CWTs) from consuned fish.

Snal I nouth bass, channel catfi sh, and wal l eye were anestheti zed wi th MS222, measured ( FL), and wei ghed (nearest 5 to 10 grans). Scal e sampl es (pectoral spi ne on channel catfish) were taken for age and grouth i nf ormation. 
St onach sampl es from smal I nouth bass and wal I eye $\geq 150 \mathrm{~mm}$ FL were col l ected with a nodi fied Seaburg stonach sampl er (Seaburg 1957). Stonach contents from channel catfi sh were obtai ned by renoving the enti re di gesti ve tract. A I stomach and di gestive tract contents were kept frozen until laboratory anal ysi s.

\section{Laborat ory Methods}

\section{Northern Squauf i sh}

In the I aboratory, di gesti ve tract sampl es were fi rst checked for CWTs with a sensor. If a CWr was present the sample bag was marked for I ater tag renoval. Sampl es were then thawed and renoved from the sampl e bags. Gut contents were stripped from the enti re di gestive tract, exami ned with a magni fyi ng I amp, and di vi ded i nto maj or prey taxa groups ( fi sh, crustacean, mol I usks, etc.). Each prey group was bl otted by placi ng the sample on ti ssue paper for 30 seconds. Prey groups were wei ghed to the nearest $0.01 \mathrm{~g}$ and returned to the sample bag. Bl otting paper, sample bags, and petri di shes uere examined with the CVr detector to ensure tags were still in the sample (occasi onally tags were l ocated in the bl otting paper).

In order to speed I ab processing of di gestive tract contents, a di gesti ve enzyne techni que was used (Petersen et al . 1990). The enzyne sol uti on was prepared usi ng I ukewarm tapuater, $2 \% \mathrm{w} / \mathrm{w}$ st rength pancreat in ( $8 x$ porci ne di gesti ve enzyne) and $1 \% \mathrm{w} / \mathrm{w}$ sodi um sul fi de. The sol ut $i$ on was pour ed into sample bags until contents were submersed. Contents were briefly sti rred to ensure al I surface areas were in contact wi th di gesti ve enzyne. Sampl es were $\mathrm{pl}$ aced i $\mathrm{n}$ a desi ccating oven at $45-50^{\circ} \mathrm{C}$ for $24 \mathrm{hr}$. After samples were removed from the oven, they were rechecked for CWTs. Tags were removed by 
shaking the bag and I ocating the tags al ong the bottom seam of the sample bag. Tags were put in a I abel ed vi al for I at er i dentification. The rest of the sampl e bag contents were poured through a 425 micron (\#40) si eve and ri nsed with tap water. A di ssecting scope and forceps were used to separate di agnostic bones (pri marily cleithra, dentaries, and opercl es) from other bones. Di agnostiic bones uere identified, pai red to enumerate prey fish consumed, and preserved wi th $95 \%$ ethanol i n I abel ed vi al s.

\section{Snal I nouth Bass}

In the I aboratory, smal I nouth bass stomach sampl es were thawed, checked for CWTs, and processed in the nanner descri bed for northern squaufi sh. Prey fi shes that were sl i ght l y di gested were easi l y i dent i fi ed to speci es. Fi shes i n advanced stages of di gestion were identified to family, genera, or species from di agnosti c bones (Hansel et al. 1988) or vertebral col ums ( H Hansel, U. S. Fi sh and Vild i fe Servi ce, unpubl i shed data). The fork I ength of prey fi shes was neasured to the nearest $\mathrm{mm}$ If a fork I ength could not be taken, the ori gi nal fork I engths of prey fi shes were est i mated from measurenents of standard I ength, nape to tai I I ength ( Vigg et al. 1991), or di agnosti c bones ( Hansel et al. 1988).

\section{Consumpti on I ndex}

A nore detailed description and deri vation for the northern squaufish CI were provi ded i n Petersen et al. (1990, 1991); the CI equation and a bri ef descri pti on from Petersen et al. (1991) is presented here for compl eteness. The consumpti on i ndex i s:

$$
\mathrm{CI}=0.0209 * \mathrm{~T}^{1.60} * \mathrm{MW}^{0.27} *\left[\mathrm{M},,, \quad * \mathrm{MGutwgt}^{-0.61}\right]
$$


where $\mathbf{T}$ is water temperat ure, $M W$ is mean predat or wei ght $(g), M$, , , is mean number of sal moni ds per predat or, and MGut ugt is mean gut uei ght per predat or (g). A I vari abl es in the $\mathbf{C l}$ are averaged over al I predators in a sampl e; is the consumption index for a collection (sample) of predators. The Cl for northern squaufi sh is not neant to be a rigorous method for esti mating the number of $\mathrm{j}$ uveni l e sal noni ds eaten per day by an average predator. The $\mathrm{Cl}$ is based on meal turnover ti ne and does not consi der certai $n$ aspects of consumption such as di el feeding patterns and evacuation rates of di fferent prey i tens.

A bootstrap resampling techni que was used to compute the di stribution characteri sti cs of northern squauf i sh $\mathrm{Cls}$ according to the methods out I i ned i n Petersen et al. (1990, 1991). For each sampl e of $\mathbf{N}$ predators, a computer program randonl y sel ected $\mathbf{N}$ i ndi vi dual predat or records and cal cul at ed a new CI. Fi ve hundred CIs were computed for each CI di stri buti on and a nean and vari ance uas cal cul ated for each bootstrap sample. The number of predat ors per bootstrap sample was set to the origi nal sample size ( $M$ ), or 60 if $N$ uas greater than 60. Data for the CI and di et anal yses were pool ed i n three di fferent patterns based on rati onal e provi ded i n Petersen et al. (1991; Fi gure 4). The use of the term"location" refers to a specific area of the reservoi $r$ sampl ed (e. g. forebay, tai I race, mid-reservoi $r$ ). The term "reservoi $r$-wi de" refers to the area of a reservoi $r$ outsi de the BRZs, whi le "BRZ onl y" is the area in a forebay or tai I race I ocation wi thi n the BRZ

\section{Snal I nouth Bass Consumpti on Rate Esti mates}

To est i mate smal I nouth bass consumpti on rates of sal moni ds, we used a 
Text
Descriptor

Sample Pooling Pattern

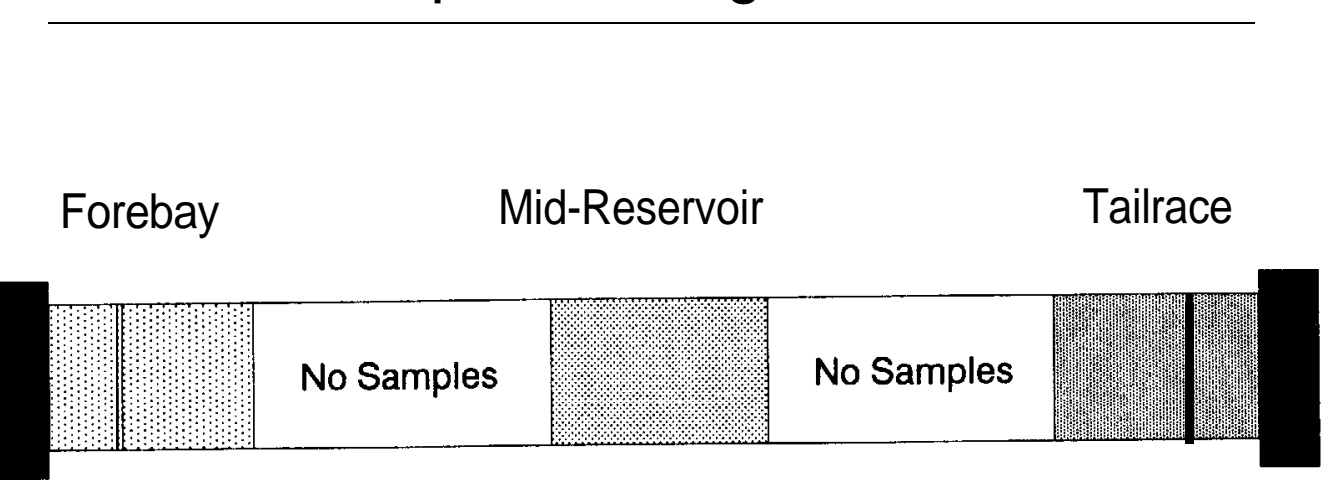

$\stackrel{n}{n}$

\section{No Samples}

No Samples
Text

Table \#

Cl Diet

$3 \quad 7 \& 8$

$6 \quad 11 \& 12$

$4 \quad 9 \& 10$

BRZ only

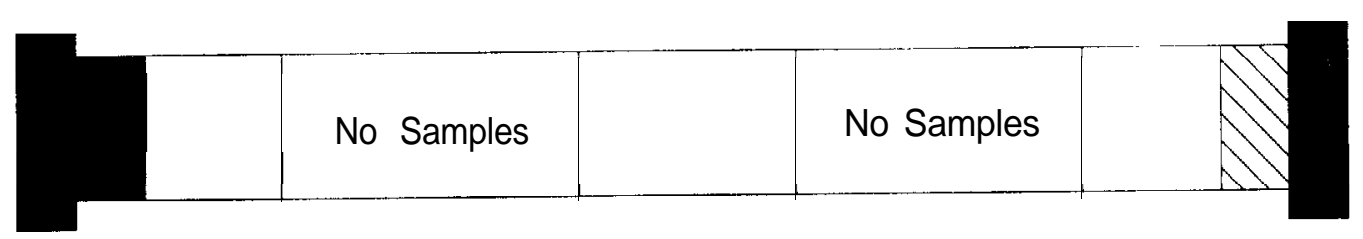

Figure 4. Sample pooling patterns for northern squawfish consumption index (Cl) and diet analyses. Each horizontal diagram represents a simple reservoir, bounded by two dams. For a particular analysis, data were pooled from areas of the reservoir having the same fill-pattern in the digram. Diagrams are not to scale. 
si mpl e neal turnover-ti me method adapt ed from Backi el (1971) and Henchman (1986). The ori gi nal neal wei ght of fi shes for each predator was esti mated based on lengths of prey fishes. Wei ghts of ingested prey fi shes were esti nat ed from I ength- wei ght regressi ons of forage fi shes ( Vi gg et al. 1991). The ori gi nal wei ghts of non-fish prey itens were esti mated by adj usting the observed non-fish wei ght with the same ratio used for fish prey weight. This assumes fish and non-fish prey itens were in si milar states of digestion. Ti me to $90 \%$ di gesti on of the esti nated neal wei ght was determi ned from di gesti on rate equati ons for smal I nouth bass (Rogers and Burl ey 1991). To det erme the number of sal moni ds consuned per day we fi rst esti mat ed consumpti on during our sampl ing peri od $(\approx 0400-1100 \mathrm{~h})$ and then adj usted the esti mates based on di el feedi ng peri odi ci ty observed i $\mathbf{n}$ J ohn Day Reservoi $\mathbf{r}$ ( Vi gg et al . 1991). Vi gg et al . (1991) found that smal I mouth bass consuned $32 \%$ of thei $\mathbf{r}$ dai l y rati on between 0400 and $1100 \mathrm{~h}$.

Bi oenergeti c Model i ng

Wbrk conti nued on the devel opment and testing of a bi oenergetics i ndex to compl i nent the CI (Petersen et al. 1990, 1991). Speci fical I y, we tri ed to est i nate seasonal grouth of northern squauf $\mathrm{i}$ sh duri ng the $\mathrm{j}$ uveni I e sal moni $d$ out-migrati on peri od, whi ch coul d be used to predi ct sal noni d consumpti on. Tho areas rel ated to detection and measurenent of seasonal grouth were exami ned: 1) sampl e si ze requi renents for esti mati ng seasonal grouth of northern squaufi sh; and 2) exami nation of al ternati ve methods to scal e agei ng for esti mating seasonal grouth at specific l ocations.

Methods for collecti on and ageing of northern squauf $i$ sh scal es were described in Petersen et al. (1991). Sampl es collected during May and 
Sept enber 1990 at the Bonnevi l le mid-reservoi r l ocati on ( ri ver km 273-285) were used for this study. Rel ati vel y I arge numbers of predators had been collected at these ti mes, providing an adequate sample for scal e sel ection. Northern squaufi sh were assi gned to si $x$ cohort groupings based on ages det ermi ned during scal e reading $(\leq 5,6,7,8,9,>9)$. Mean wei ghts were cal cul at ed for each cohort for May and Septenber and compared. To det er mi ne how nean wei ght changes during spring and sumer we esti nated seasonal grouth by exami ni ng typi cal wei ght di stri buti ons of northern squaufi sh sampl ed duri ng 1983- 86 from MtNary Dam boat restricted zone (BRZ) or wi thi $\mathbf{n}$ J ohn Day Reservoi r. Mean wei ght was cal cul ated by month for northern squauf i sh $\geq 190 \mathrm{~g}$ ( about 250mm FL). Data uere exami ned pri marily for withi $n$-year trends, rather than bet ween- year patterns. 


\section{RESULTS}

Catch

In 1991, a total of 3755 target predators were capt ured. Northern squauf i sh were the nost abundant $(56 \%, n=2118)$, fol I oved by smal I mouth bass (41\%, $n=1527)$, channel catfi sh $(<3 \%, n=100)$ and wal I eye $(<1 \%, n=10)$. A I wal I eye were capt ured i n John Day Reservoi r (Tabl e 2, Fi gure 5).

of the 1821 northern squauf i sh capt ured in the Snake Ri ver, $45 \%$ were capt ured from the three tai I race I ocations. The I argest number of northern squaufi sh were sampl ed at Lower Granite tail race BRZ (22\% of total catch). Thi rty percent of the northern squauf i sh were capt ured i $n$ the upper reaches of the study area (Lower Granite Upper, Clearwater Ri ver, Asoti n, and Rogersburg I ocations; $n=643$ ). The sex ratio for northern squauf $i$ sh whose sex was det er mi ned was $43 \% \mathrm{mal}$ es and $57 \%$ fenal es. $\mathbf{N}$ nety-seven percent of the northern squauf i sh had devel oping gonads. However, at Lower Monumental midreservoi $r \quad 17 \%$ of the $\mathrm{fish}$ had gonads that were i mature. Northern squaufish from the Snake and Clearuater ri vers were si gni fi cantly snal ler ( Pt Q. 001 ; $x$ FL= 319 for $\mathbf{m a l ~ e s , ~} \mathbf{x}=376 \mathbf{m m}$ for fenal es) than fi sh capt ured from the John Day Reservoi $r$ ( $\chi$ FL= $353 \mathrm{~mm}$ for mal es, $\chi=420 \mathrm{~mm}$ for fenal es; Tabl e 3).

Dai l y mi num and naxi mum sampl e si zes were based on data collected i n J ohn Day Reservoi $r$ (Petersen et al . 1990). We capt ured the mi ni mum of 60 northern squauf i sh (15/day) at 8 of 15 Snake Ri ver I ocations, and in the BRZ of MtNary tai I race. The maxi mum of 120 (30/day) northern squauf i sh was col lected at 2 of 15 I ocations in the Snake Ri ver, and in the BRZ of MtNary tai I race in the spring. In general, it was easi er to capt ure target numbers 
Table 2. Summary of maj or predators col l ected duri ng the 1991 northern squauf i sh consumpti on i ndexing sampl ing. N=Nunber, $\mathrm{M} M \mathrm{Ml} \mathrm{e}, \mathrm{F}=\mathrm{Femal}$, U=Uni dent $i$ fi ed sex, SMB=Snal I nout $h$ bass, CHC=Channel cat $f i$ sh, WAL=MII l eye. See Tabl e 1 for descri pti on of I ocations.

RESERVO R NORTHERN SQUAVI SH

SMB

CHC WAL Locati on

Snake Ri ver

I CE HARBOR

\begin{tabular}{|c|c|c|c|c|c|c|c|}
\hline $\begin{array}{l}\text { 1.Ice Harbor Fb } \\
\text { 2.Ice Harbor } \mathrm{Mr} \\
\text { 3. Lower Mbnunental }\end{array}$ & $\mathrm{Tr}$ & $\begin{array}{r}5 \\
17 \\
80\end{array}$ & $\begin{array}{r}1 \\
6 \\
32\end{array}$ & $\begin{array}{r}3 \\
8 \\
47\end{array}$ & $\begin{array}{l}1 \\
3 \\
1\end{array}$ & $\begin{array}{r}64 \\
161 \\
74\end{array}$ & $\begin{array}{l}4 \\
2 \\
2\end{array}$ \\
\hline
\end{tabular}

LOVER MONUMENTAL

4. Lower Mnument al

5. Lower Monumental Mr 135

6. Little Goose Tr

275

63

137

85
16
468

43

10

7. Little Goose Fb

8. Little Goose M

9. Lower Granite Tr

203

59

5
133

133

166

199

14.Clearwater R.

R.

FREEFLOWING RIVER

15.Rogersburg

147

Tot al

1821

21
0
46
75
57

38

5

82

88

131

42
6
261

0
23

9

51
111
105

$\begin{array}{rl}1 & 0 \\ 26 & 0 \\ 42 & 0\end{array}$

49
129

125

179

65

$\begin{array}{rl}0 & 0 \\ 17 & 0 \\ 0 & 0\end{array}$

56

70

75

64

42

$\begin{array}{ll}0 & 0 \\ 0 & 0 \\ 0 & 0 \\ 2 & 0 \\ 0 & 0\end{array}$

Col unbi a Ri ver

\section{JOHN DAY \\ Spring \\ 16.John Day Fb \\ 17.John Day M \\ lS.McNary Tr}

Total

Summer

16. John Day Fb

17.John Day Mr

18.McNary Tr

Total

Total

(1)

24
6
148

178

18

3

98

119
55

87

754

1002

65

87

1329

$0 \quad 0$

$96 \quad 0$ 


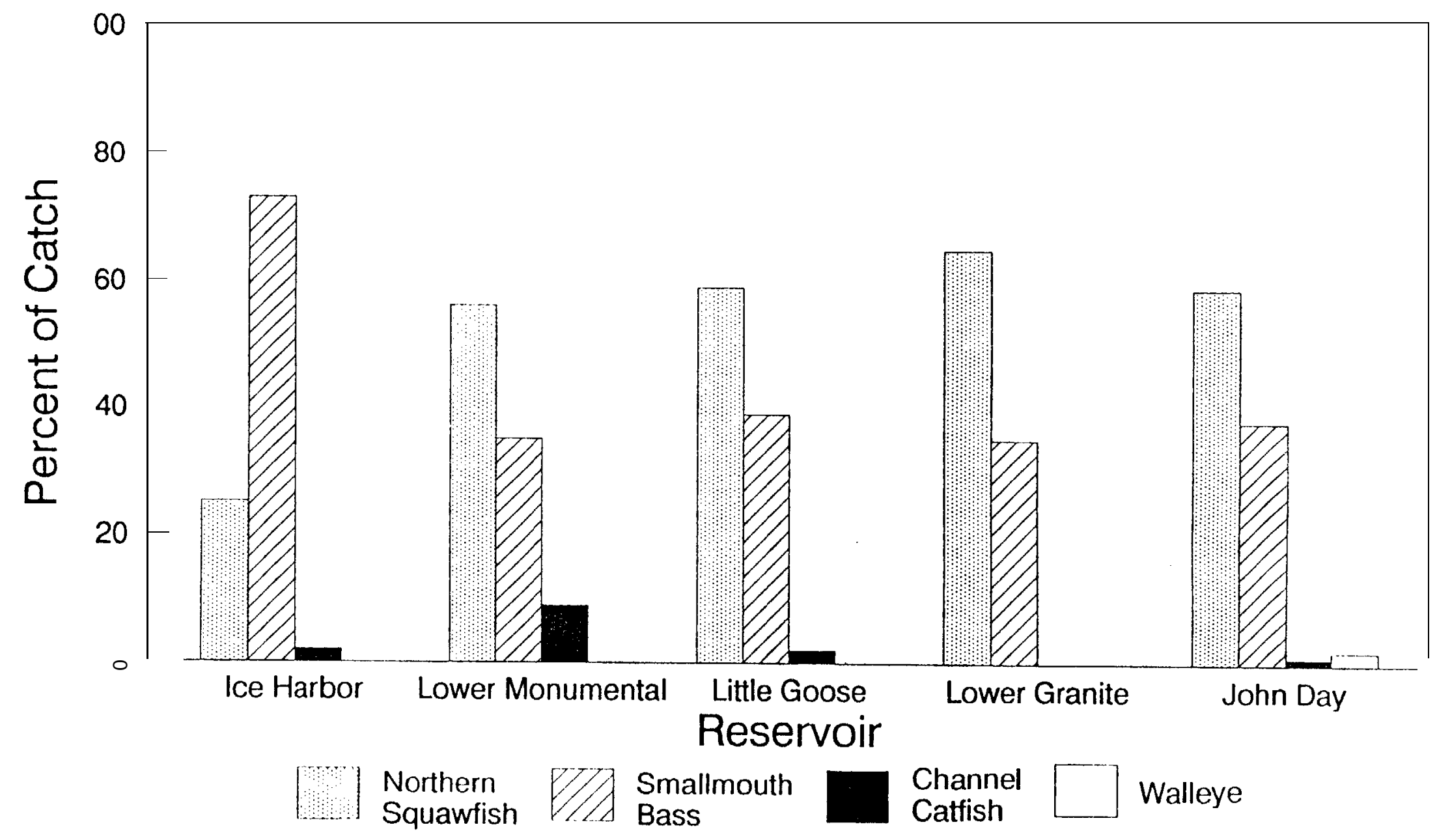

Figure 5. Percent of catch of predators per reservoir during the 1991 consumption indexing. Reservoirs are from dam to dam including BRZs. Lower Granite reservoir includes transects from the dam to the first set of rapids. 
of nort hern squauf $i$ sh wi thi $n$ BRZs than non-BRZs. At I ocati ons away from the dans it uas nore diff i cult to sample adequate numbers of northern squauf i sh except at the four si tes above Lower Grani te mid-reservoi $r$ and during turbid condi ti ons.

Snal I nouth bass were nore numerous than northern squauf ish at al I forebay and mid-reservoi $r$ I ocati ons except for Lower Grani te forebay and Lower Monumental mid-reservoi $r$ where northern squauf i sh compri sed about $50 \%$ of the total catch (Table 2). Thi rty-ni ne percent of the smal I nouth bass were col l ected from the four $\mathrm{m} d$-reservoi $r$ I ocati ons $(n=521)$ and $22 \%$ from the four forebay I ocati ons ( $n=298)$. Snal I nouth bass accounted for 84 to $93 \%$ of the predators at the mid-reservoi r l ocations of I ce Harbor, Little Goose, and Lower Granite. At forebay and tai I race I ocati ons the maj ority (69\%) of smal I nouth bass were capt ured in non-BRZ areas. Snal I mouth bass capt ured i n the free-fl owing Rogersburg I ocati on were $14 \%$ I arger (based on mean FL) than those capt ured el sewhere ( Table 3).

A dramatic i ncrease i n turbi di ty caused by heavy rai ns i n eastern Whshi ngt on and Oregon was observed on 21 May at Li ttl e Goose mid-reservoi r and at subsequent downst ream I ocations. i ncreased catches of nost predators ( northern squauf i sh, channel catfi sh, bul I heads ( 1 . spp), and crappi e (Ponoxi s spp.) were associ ated wi th the hi gher turbi dity, nost notably in midreservoi $r$ l ocations where catch numbers were l ow three weeks earlier.

Non-target predators, speci es whi ch have shown evi dence of pi sci vory, were al so col l ected. These i ncl uded bl uegi Il (Lepomis macrochi rus $n=3$ ), pumpki nseed ( $L$. qi bbosus $n=2$ ), yel I ow perch (Perca flavescens $n=103$ ), crappi e ( $n=39)$, and bul I head ( $n=33)$. N neteen fish that appeared to be northern squauf i sh $x$ chi sel nouth (Acrochei I us al utaceus) hybri ds (Patten 1960) were 
al so col l ected. Hybri ds were sampl ed in al I Snake Ri ver reservoi rs except Ice Harbor. I nci dental fi sh speci es comonl y observed i ncl uded: suckers (Cat ostomus spp.), carp (Cypri nus caroi o), and chi sel nouth. Less commonl y

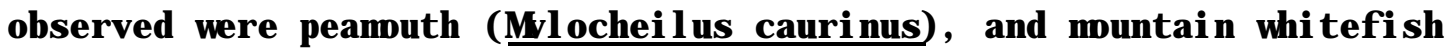
(Prosopi um williansoni). Rarel y seen speci es i ncl uded sandrol l ers (Percoosi s transmont ana), three-spi ne sti ckl eback (Gasterosteus acul eat us), and pri ckl y scul pi n (

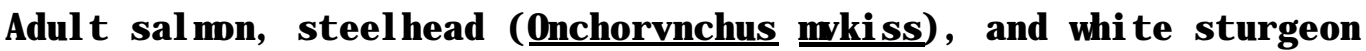
(Aci penser transmont anus) were occasi onal I y shocked duri ng sampl ing. The sampling crew stopped el ectrofishing to al low these fish to recover or drift out of the current field.

Di et of Northern Squauf i sh

In the I aboratory, 1408 northern squaufi sh di gesti ve tract sampl es from Snake Ri ver I ocati ons were anal yzed. The overal I di et of northern squaufi sh was domi nated by $\mathrm{fi}$ sh and crustaceans $(55.0 \%$ and $26.3 \%$ respecti vel y; Table 4). Fi sh were the nost i mportant prey item by wei ght for northern squauf i sh from nost BRZ areas (Table 5) as vel I as nany non- BRZ areas (Table 6). Crustaceans were of ten the dominant prey item of northern squauf ish in reservoi $r$ - wi de areas. Crayfish made up the greatest portion of crustacean wei ght. Amphi pods ( pri mari l y Corpohi um sp.) were al so present, especi al I y i n snal I northern squauf i sh ( $350 \mathrm{~mm} \mathrm{FL)}$.

A t otal of 885 sal moni ds (mean 0.63 salmonids.fish ${ }^{-1}$ ) were consumed by northern squauf i sh (Table 7). Northern squaufi sh collected wi thi $n$ BRZ areas cont ai ned si gni fi cantl y hi gher numbers of j uveni l e sal moni ds than reservoi $r$ wi de areas $\left(X_{B R Z}=0.83\right.$ salmonids $f f_{s h}{ }^{-1} ; X_{R E S}=0.53$ salmonids $\cdot$ fish $^{-1} ; P<0.001$; 
Tabl e 4. Gut cont ent of northern squauf i sh col I ected at I ocat i ons i n I ower Snake Ri ver reservoi rs and J ohn Day Reservoi $r$ of the Col umbi a Ri ver during 1991. Gut contents ( $\%$ are the mean of percentages of i ndi vi dual northern squauf i sh. Crust . =crustacean; Mol I . =mol I usk; Tr=Tai I race; Fb=For ebay; M =M dreservoi $r$; and Up=Upper reservoi $r$.

\section{RESERVO R}

Locati on

\section{Mean \% $N$ gut ut empty \\ (g) guts}

GT CONTENTS $(\%)$

Fi sh Crust. Mo??. I nsect PI ant Other

SNAKE RI VER

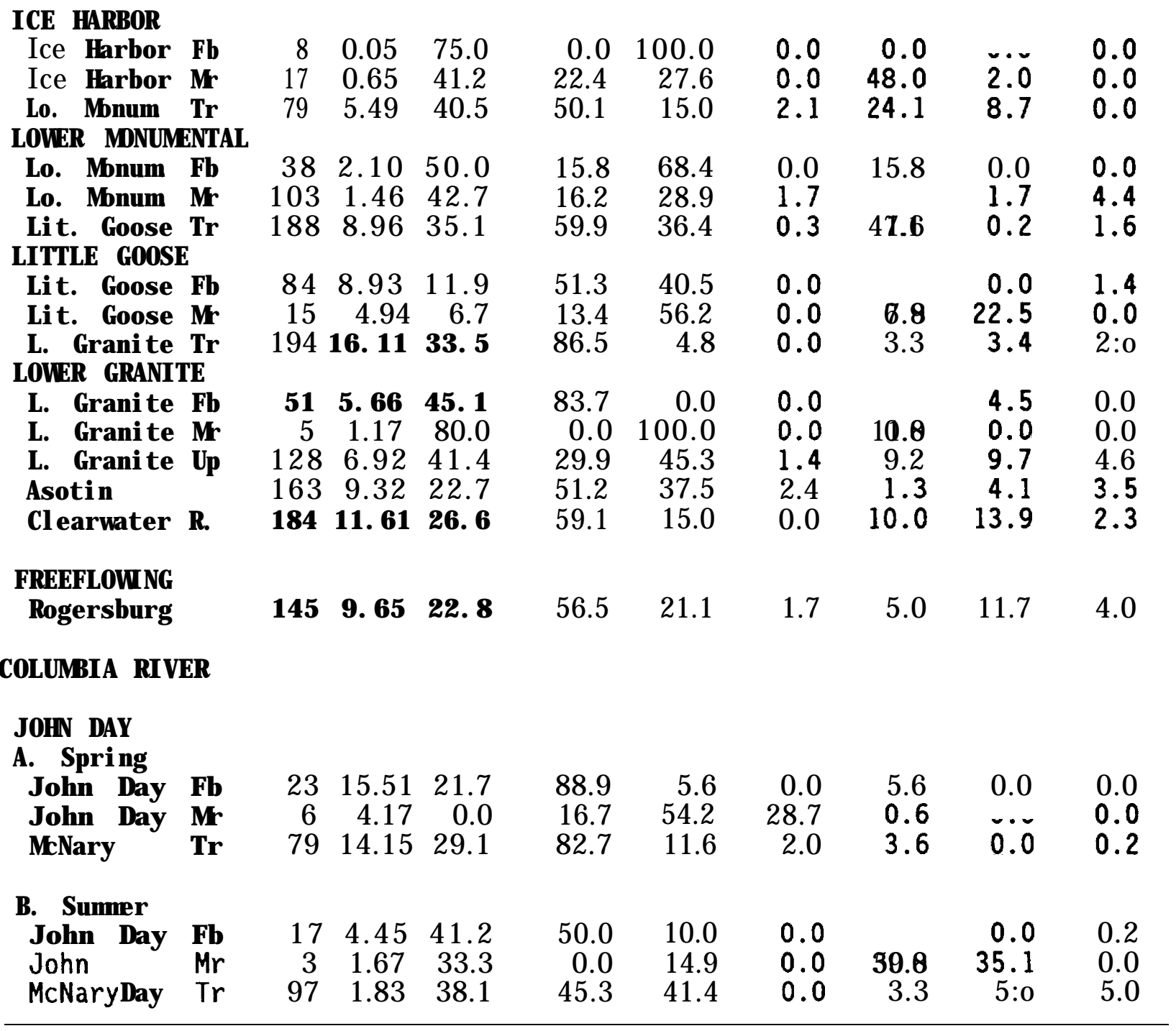


Table 5. Di et summary of northern squauf i sh col l ected wi thi $n$ dam BRZs i $n$ the I ower Snake Ri ver reservoi rs and John Day Reservoi $r$ of the Col unbi a Ri ver during 1991. See Table 4 for explanation of col ums.

RESERVO R

Locati on

(i n BRZ)

\section{Mean \% \\ N gut ut empty}

(g) guts
GT CONTENTS $(\%$

Fi sh Crust. Mo??. I nsect PI ant Other

SNAKE RI VER

ICE HARBOR

Ice Harbor Fb

Lo. Monum Tr 55

LOVER MONUMENTAL

Lo. Monum Fb 25

Lit. Goose Tr 127

LI TTLE GOOSE

Lit. Goose Fb

L. Granite Tr

LOVER GRAN TE

L. Granite Fb

$\begin{array}{lll}0 & . . & \end{array}$

4. $53 \quad 36.4$

$-\cdot$

$-$

2. 9

29. 5

7. 8

0.0

1. 6060.0

30.0

60. 0

0. $0 \quad 10.0$

0.0

0.0

59.9

35.0

0.0

2. 4

0.3

2. 4

53. 4

37.4

0.0

7.7

0.0

1.5

92.1

1.9

0.03 .3

2. 8

0.0

83. 7

0. 0

$0.0 \quad 11.8$

4. 5

0.0

\section{COLUMB A RI VER}

J OHN DAY
A Spring J ohn Day MtNary $\begin{array}{llll}\text { Fb } & 17 & 14.79 & 23.5\end{array}$
$\begin{array}{llll}\text { Tr } & 58 & 15.77 & 27.6\end{array}$
92. 3
7.7
0.0
0.0
0.0
0.0
93. 4
6.6
0.0
0.0
0.0
0.0

B. Summer J ohn Day MeNary

$\begin{array}{llll}\mathrm{Fb} & 12 & 6.23 & 33.3 \\ \mathrm{Tr} & 78 & 2.02 & 20.5\end{array}$

$\begin{array}{llll}\operatorname{Tr} & 78 & 2.02 & 20.5\end{array}$

50.0

0.0

$0.0 \quad \ddot{0} 0$

$50.3 \quad 42.0$

0.0
42.0

0.0

$40.0 B$

0.0

$\begin{array}{ll}3.8 & 3.8\end{array}$ 
Table 6. Di et summary of northern squauf i sh col l ected in reservoi $r$ - wi de areas ( excl udi ng BRZ' s) i n I ower Snake Ri ver reservoi rs and J ohn Day Reservoi $r$ of the Col unbi a Ri ver during 1991. See Table 4 for expl anati on of col ums.

\section{RESERVO R \\ (excluding BRZ's)}

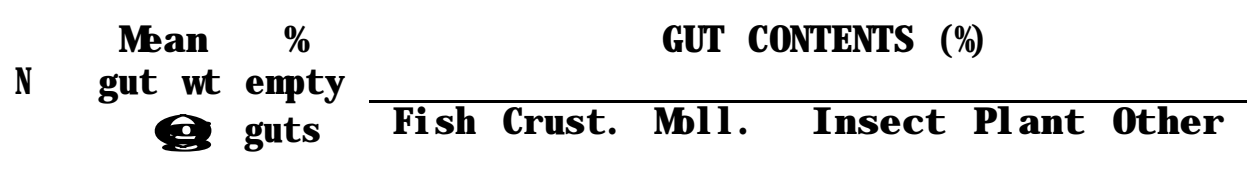

SNAKE RI VER

$\begin{array}{lrrrrrrrrr}\text { ICE HARBOR } & 42 & 1.15 & 54.8 & 27.6 & 33.7 & 0.0 & 30.5 & 8.3 & 0.0 \\ & & & & & & & & 0.9 & 2.4 \\ \text { LOIEBE MESDENNTAL } & 193 & 15.4 B & 39.3 & 54.2 & 36.8 & 0.0 & 24.8 & 8.2 & 4.8 \\ \text { LONER GRAN TE } & 488 & 2.24 & 30.1 & 35.6 & 57.9 & 0.0 & 4.3 & 1.3 & 0.8 \\ \text { FREEFLOW NG } & 145 & 9.65 & 22.8 & 56.5 & 21.1 & 1.7 & 5.0 & 11.7 & 4.0\end{array}$

COLUMB A RI VER

J OHN DAY

Spri ng

$\begin{array}{lll}34 & 9.46 & 23.5 \\ 27 & 0.97 & 55.6\end{array}$

52.2

25. 8

10. 5

11. 2

0.0

0.4 Summer
16. 735.8
0.0

25. 0

14. 2

8. 3 
Table 7. Prey fish consuned by northern squaufi sh (SQF) col lected at I ocati ons in I ower Snake Ri ver reservoi rs and J ohn Day Reservoi $r$ of the Col umbi a Ri ver duri ng 1991. FLf ork I ength; Mean Fi sh W. =nean prey fi sh mass (g) per predator; \% smolts= percent of the total number of fi sh consuned that

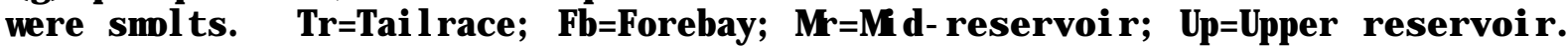

\section{PREDATORS}

$\begin{gathered}\text { RESERVO R } \\ \text { Locati on }\end{gathered}$
N $\quad \begin{gathered}\text { Mean } \\ \text { FL } \mathbf{m})\end{gathered}$

SNAKE RI VER

I CE HARBOR

I ce Harbor Fb 8

I ce Harbor Mr $17 \quad 296$

Lo. Monum Tr $79 \quad 361$

LOVER MONUMENTAL

Lo. Monum Fb 38

Lo. Mbnum Mr $103 \quad 280$

Lit. Goose Tr $188 \quad 319$

LI TTLE GOOSE

Li t. Goose Fb 84

Li t. Goose Mr $15 \quad 319$

L. Granite Tr $194 \quad 371$

LOVER GRAN TE

L. Granite Fb 59

L. Grani te Mr 5437

L. Grani te Up 128

Asoti n

$163 \quad 369$

$\begin{array}{llll}\text { Q ear wat er } & \text { R. } & \mathbf{1 8 4} & 370\end{array}$

FREEFLOW NG

Rogersburg

$145 \quad 370$

PREY FI SH CONSUMED

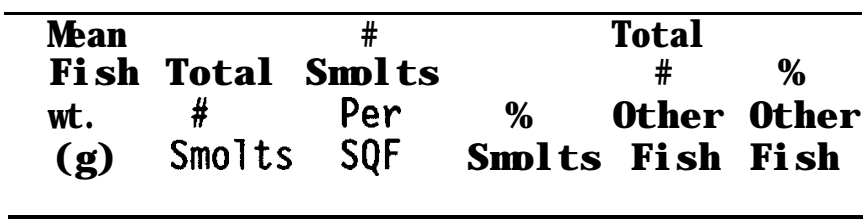

$0.00 \quad 0$

$0.10 \quad 0$

4. $76 \quad 30$

0.000

0.000

0.380

0.0

60.0

$0.079 \quad 100.0$

0.93

0.37

7.41

3

0

94

0.000

0.0

77.0

0.500

0.690

$6.71 \quad 58$

0.59

15.76

0. 000

98. 3

0. 0

94.4

254

1.309

$5.08 \quad 46$

0.00

2.48

6.20

9.10

$7.50 \quad 101$

0.780

0.000

93.9

0.250

0.681

0.853

0. 69787.
87.1

15

$\begin{array}{lll}91.4 & 3 & 8.6\end{array}$

$\begin{array}{lll}71.6 & 44 & 28.4\end{array}$

$\begin{array}{lll}84.9 & 28 & 15.1\end{array}$

12.9

\section{COLUMBIA RIVER}

\section{J OHN DAY}

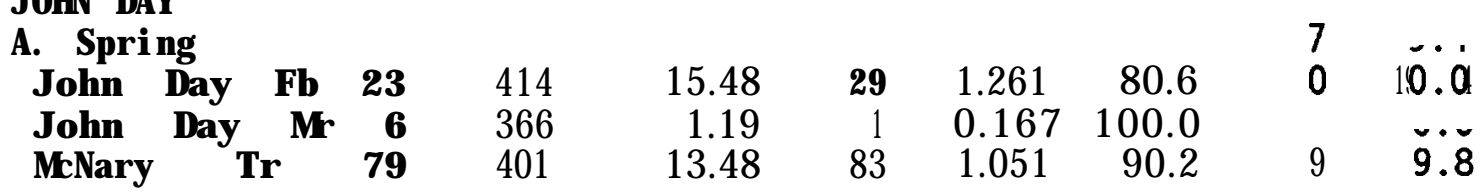

\section{B. Summer}

$\begin{array}{lrrrrrlrrr}\text { J ohn Day } & \text { Fb } & \mathbf{1 7} & 399 & 2.68 & \mathbf{9} & 0.529 & 100.0 & 0 & 0.0 \\ \text { J ohn Day } & \mathbf{M r} & \mathbf{3} & 398 & 0.00 & \mathbf{0} & 0.000 & -- & 0 & \\ \text { MtNary } & \text { Tr } & \mathbf{9 7} & 389 & 1.28 & 28 & 0.289 & 53.8 & 24 & 46.2 \\ \end{array}$


Tabl e 8. Prey fi sh consumed by northern squauf i sh (SQF) col l ected wi thi $n$ dam BRZ' s i n I ower Snake Ri ver reservoi rs and J ohn Day Reservoi $r$ of the Col unbi a Ri ver during 1991. See Table 5 for expl anation of col ums.

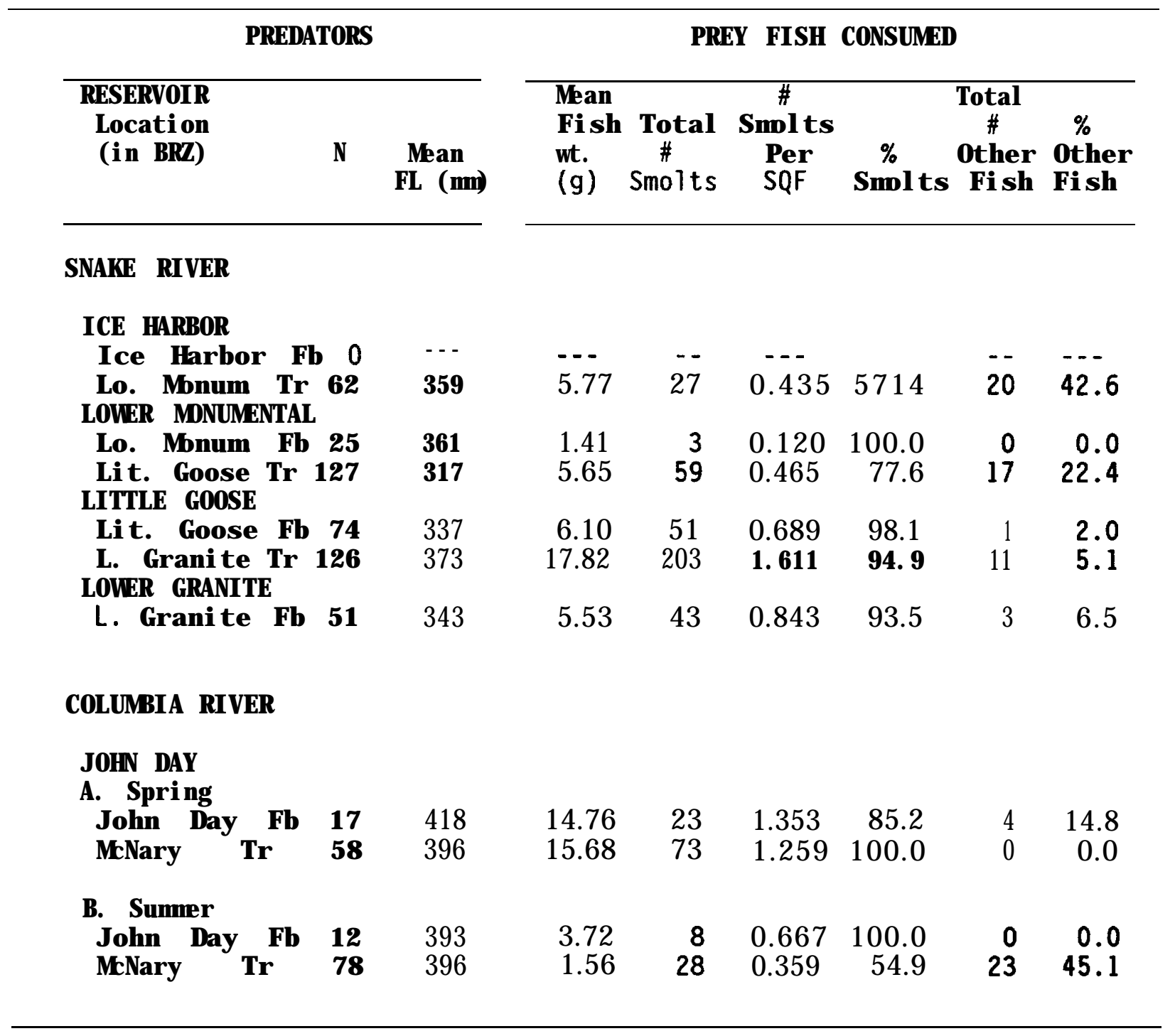


Table 9. Prey fish consuned by northern squaufi sh (SQF) col lected in reservoi $r$ - wi de areas i n I ower Snake Ri ver resrvoi rs and J ohn Day Reservoi $r$ of the Col unbi a Ri ver duri ng 1991. See Table 5 for expl anation of col ums.

PREDATORS

RESERVO R

( excl udi ng

BRZ's)
N Mean
PREY FI SH CONSUMED

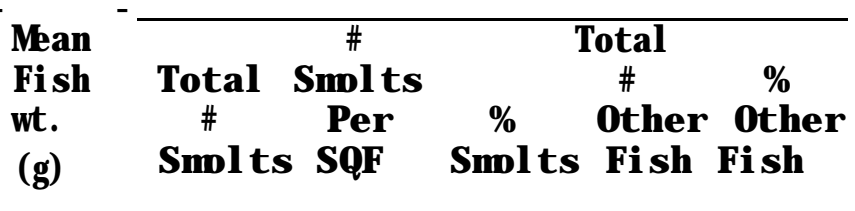

SNAKE RI VER

ICE HARBOR $42 \quad 330$

297

LOVER MDNUMENTAL 177

LI TTLE GOOSE

LOVER GRAN TE

ROGERSBURG

$93 \quad 361$

$488 \quad 372$

$145 \quad 370$

(Free- Fl owi ng)

COLUMBI A RI VER

J OHN DAY

Spri ing

Summer
0.48

4.08

10.06

6.20

$7.50 \quad 101$
0.071

0.198

0.624

0.621

0.697
50.0

52.2

89.2

84.6

87.1
50.0

3: $\quad 47.8$

$7 \quad 10.8$

$55 \quad 15.4$

$15 \quad 12.9$ $\begin{array}{ll}36 & 394 \\ 27 & 376\end{array}$

7.63

20

0.556

62.5

$12 \quad 37.5$

0.13

$1 \quad 0.037$

50.0

150.0 
Tabl es 8 and 9) northern squauf $\mathrm{i}$ sh col l ected at $\mathrm{m}$ d-reservoi $r$ si tes di d not contai $n$ any sal moni ds. In contrast, northern squauf i sh collected at Lower Grani te upper reservoi r, Asoti $n$, Cl earuater, and Rogersburg I ocati ons consumed hi gh numbers of sal moni ds ( Table 7).

Other species of preyf $i$ sh comprised onl y $17 \%$ of the total number of $f i s h$ i ngested by northern squauf i sh. Scul pi ns were the predomi nant non-sal moni d fi sh i ngested by northern squaufi sh in the free-fl owing areas. In reservoi $r$ wi de areas, fi sh consuned by northern squauf i sh were predomi nant l y i ctal uri ds and centrarchi ds.

We exami ned the guts of 225 northern squauf i sh from J ohn Day Reservoi $r$. The overal I di et of northern squauf $i$ sh was dom nated by $f i$ sh and crustaceans (62. 8\% and 24. 3\% respecti vel $y$, Table 4). General l y, wi thi $n$ the BRZs fi sh were the pri mary prey item with sal nonids comprising $83 \%$ of the total prey fish ( Table 8). During the summer sampl ing peri od crustaceans and i nsects becane more i mportant. Reservoi $r$-wi de, the trend was si $\mathrm{m} /$ ar except that during the sumer sampl ing peri od crustaceans and i nsects were the maj or components of the di et with fish having a secondary rol e (Table 6). The greatest nunber of sal moni ds per northern squauf $i$ sh were from fi sh coll ected wi thi $n$ the BRZs during the spring, wi th J ohn Day forebay bei ng the hi ghest (1.4 salmonids.fish-1 Table 8). Generally, sumer samples had a hi gher percentage of empty di gestive tracts than spring samples.

Di et of Snal I mouth Bass

We anal yzed st onach contents of 1145 snal I mouth bass col l ected from Snake Ri ver l ocations. Crustaceans (pri marily crayfish) domi nated the di ets of snal I mouth bass $(64 \%$, fol I owed by fi sh ( $27 \%$ Tabl e 10$)$, wi th the excepti on 
Tabl e 10. Di et sumary of smal I nouth bass i $n$ reservoi $r$-wi de ar eas (i ncl udi ng BRZs) i $n$ the I ower Snake Ri ver and J ohn Day Reservoi $r$ of the Col unbi a Ri ver during 1990. See Table 4 for expl anation of col ums.

\begin{tabular}{|c|c|c|c|c|c|c|c|c|c|}
\hline \multirow{2}{*}{\multicolumn{2}{|c|}{$\begin{array}{l}\text { RESERVO R } \\
\text { Fork } \\
\text { I engt } \mathbf{h}(\mathrm{mm})\end{array}$}} & \multirow{2}{*}{$\begin{array}{l}\text { Mean } \\
\text { gut ut } \\
\text { N (9) }\end{array}$} & \multirow{2}{*}{$\begin{array}{l}\text { \% } \\
\text { empty } \\
\text { gut s }\end{array}$} & \multicolumn{5}{|c|}{ DI GESTI VE TRACT CONTENIS (\%) } & \multirow[b]{2}{*}{ Ot her } \\
\hline & & & & Fi sh & Crust. & Mol I . & I nsect & PI ant & \\
\hline \multicolumn{10}{|l|}{ SNAKE RI VER } \\
\hline $\begin{array}{l}\text { ICE HARBOR } \\
150-199 \\
\mathbf{2 0 0 - 2 4 9} \\
\mathbf{2 5 0 - 2 9 9} \\
>300 \\
\text { Total }\end{array}$ & $\begin{array}{r}70 \\
112 \\
50 \\
31 \\
263\end{array}$ & $\begin{array}{l}0.17 \\
0.85 \\
1.03 \\
0.96 \\
0.72\end{array}$ & $\begin{array}{l}47.1 \\
43.8 \\
38.0 \\
32.3 \\
42.2\end{array}$ & $\begin{array}{l}16.1 \\
23.8 \\
28.3 \\
51.2 \\
26.6\end{array}$ & $\begin{array}{l}72.1 \\
57.1 \\
53.1 \\
35.1 \\
56.9\end{array}$ & $\begin{array}{l}1.6 \\
0.0 \\
0.0 \\
0.0 \\
0.4\end{array}$ & $\begin{array}{r}2.7 \\
11.1 \\
3.1 \\
8.4 \\
7.1\end{array}$ & $\begin{array}{l}0.0 \\
0.0 \\
4.0 \\
0.0 \\
0.8\end{array}$ & $\begin{array}{r}7.6 \\
8.2 \\
11.6 \\
5.3 \\
8.3\end{array}$ \\
\hline $\begin{array}{l}\text { LOVER MONUME } \\
150-199 \\
200-249 \\
250-299 \\
>300 \\
\text { Total }\end{array}$ & $\begin{array}{r}\text { ENTA } \\
29 \\
93 \\
71 \\
28 \\
221\end{array}$ & $\begin{array}{l}\text { AL } \\
0.32 \\
0.82 \\
1.02 \\
3.92 \\
1.21\end{array}$ & $\begin{array}{l}51.7 \\
33.3 \\
28.2 \\
35.7 \\
34.4\end{array}$ & $\begin{array}{r}4.4 \\
17.3 \\
23.2 \\
43.8 \\
21.4\end{array}$ & $\begin{array}{l}86.0 \\
80.4 \\
71.1 \\
44.7 \\
73.3\end{array}$ & $\begin{array}{l}0.0 \\
0.0 \\
0.0 \\
0.0 \\
0.0\end{array}$ & $\begin{array}{l}2.4 \\
1.9 \\
3.0 \\
6: 0 \\
2.8\end{array}$ & $\begin{array}{l}0.0 \\
0.0 \\
2.0 \\
5.6 \\
1.4\end{array}$ & $\begin{array}{l}7.1 \\
0.4 \\
0.8 \\
0.0 \\
1.1\end{array}$ \\
\hline $\begin{array}{l}\text { LI TTLE COOSE } \\
150-199 \\
200-249 \\
250-299 \\
>\mathbf{3 0 0} \\
\text { Total }\end{array}$ & $\begin{array}{r}\mathbf{E} \\
79 \\
130 \\
79 \\
26 \\
\mathbf{3 1 4}\end{array}$ & $\begin{array}{l}0.41 \\
1.14 \\
2.60 \\
7.03 \\
1.81\end{array}$ & $\begin{array}{r}29.1 \\
15.4 \\
12.7 \\
7.7 \\
17.5\end{array}$ & $\begin{array}{l}10.8 \\
16.6 \\
16.4 \\
17.5 \\
15.4\end{array}$ & $\begin{array}{l}88.3 \\
78.6 \\
80.1 \\
74.0 \\
80.7\end{array}$ & $\begin{array}{l}0.0 \\
0.1 \\
0.0 \\
0.0 \\
0.0\end{array}$ & $\begin{array}{l}0.9 \\
3.4 \\
3.0 \\
4.2 \\
2.8\end{array}$ & $\begin{array}{l}0.0 \\
0.1 \\
0.0 \\
0.2 \\
0.0\end{array}$ & $\begin{array}{l}0.1 \\
1.3 \\
0.5 \\
4.2 \\
1.1\end{array}$ \\
\hline $\begin{array}{l}\text { LOVER GRAN T } \\
150-199 \\
200-249 \\
250-299 \\
>300 \\
\text { Tot al }\end{array}$ & $\begin{array}{r}\text { TE } \\
55 \\
73 \\
78 \\
49 \\
255\end{array}$ & $\begin{array}{l}0.29 \\
0.60 \\
2.39 \\
6.41 \\
2.18\end{array}$ & $\begin{array}{l}60.0 \\
45.2 \\
21.8 \\
14.3 \\
34.8\end{array}$ & $\begin{array}{r}9.1 \\
15.7 \\
39.4 \\
59.5 \\
34.7\end{array}$ & $\begin{array}{l}77.3 \\
78.2 \\
56.3 \\
35.3 \\
59.1\end{array}$ & $\begin{array}{l}0.0 \\
0.0 \\
0.0 \\
0.0 \\
0.0\end{array}$ & $\begin{array}{r}13.6 \\
6.1 \\
2.1 \\
0.3 \\
4.2\end{array}$ & $\begin{array}{l}8.8 \\
1.7 \\
2.5 \\
1.3\end{array}$ & $\begin{array}{l}0.0 \\
0.0 \\
0.5 \\
2.4 \\
0.8\end{array}$ \\
\hline $\begin{array}{l}\text { ROGERSBURG } \\
150-199 \\
200-249 \\
\mathbf{2 5 0 - 2 9 9} \\
>\mathbf{3 0 0} \\
\text { Total }\end{array}$ & $\begin{array}{r}1 \\
3 \\
39 \\
37 \\
80\end{array}$ & $\begin{array}{l}0.00 \\
0.31 \\
0.91 \\
2.46 \\
1.59\end{array}$ & $\begin{array}{r}100.0 \\
33.3 \\
33.3 \\
29.7 \\
32.5\end{array}$ & $\begin{array}{l}32.0 \\
65.4 \\
70.3 \\
66.5\end{array}$ & $\begin{array}{r}0.0 \\
19.4 \\
15.7 \\
16.9\end{array}$ & $\begin{array}{l}0.0 \\
0.0 \\
0.0 \\
0.0\end{array}$ & $\begin{array}{r}18.0 \\
7.5 \\
2.1 \\
5.3\end{array}$ & $\begin{array}{r}50.0 \\
4.5 \\
8.8 \\
8.2\end{array}$ & $\begin{array}{l}0.0 \\
3.2 \\
3.1 \\
3.0\end{array}$ \\
\hline
\end{tabular}


Tabl e 10 cont i nued.

\begin{tabular}{|c|c|c|c|c|c|c|c|c|c|}
\hline \multirow{2}{*}{\multicolumn{2}{|c|}{$\begin{array}{l}\text { RESERVO R } \\
\text { Fork } \\
\text { l engt } \mathbf{h}(\mathbf{m})\end{array}$}} & \multirow{2}{*}{$\begin{array}{l}\text { Mean } \\
\text { gut ut } \\
N(g)\end{array}$} & \multirow{2}{*}{$\begin{array}{l}\% \\
\text { empty } \\
\text { gut s }\end{array}$} & \multicolumn{6}{|c|}{ D GESTI VE TRACT CONTENIS $(\%$} \\
\hline & & & & Fi sh & Crust. & Mol I . & Insect & PI ant & Other \\
\hline \multicolumn{10}{|c|}{ COLUMBI A R VER } \\
\hline $\begin{array}{c}\text { J OHN DAY } \\
\text { A Spri ng } \\
150-199 \\
200-249 \\
250-299 \\
>300 \\
\text { Tot al }\end{array}$ & $\begin{array}{r}14 \\
36 \\
19 \\
9 \\
80\end{array}$ & $\begin{array}{l}0.11 \\
1.01 \\
1.38 \\
\mathbf{4 . 1 5} \\
\mathbf{1 . 4 6}\end{array}$ & $\begin{array}{r}57.1 \\
16.7 \\
36.8 \\
0.0 \\
27.5\end{array}$ & $\begin{array}{l}32.7 \\
30.7 \\
82.8 \\
34.2\end{array}$ & $\begin{array}{l}67.3 \\
64.6 \\
40.2 \\
62.3\end{array}$ & $\begin{array}{l}0.0 \\
0.0 \\
0.0 \\
0.0\end{array}$ & $\begin{array}{l}0.0 \\
4.7 \\
0.1 \\
0.0 \\
2.4\end{array}$ & $\begin{array}{l}0.0 \\
0.1 \\
0.0 \\
0.0\end{array}$ & $\begin{array}{l}0.0 \\
0.0 \\
5.0 \\
0.0 \\
1.0\end{array}$ \\
\hline $\begin{array}{l}\text { B. Summer } \\
\text { 150-199 } \\
200-249 \\
\mathbf{2 5 0 - 2 9 9} \\
>\mathbf{3 0 0} \\
\text { Tot al }\end{array}$ & $\begin{array}{l}12 \\
37 \\
26 \\
21 \\
96\end{array}$ & $\begin{array}{l}0.60 \\
2.12 \\
2.49 \\
6.82 \\
3.06\end{array}$ & $\begin{array}{r}8.3 \\
21.6 \\
11.5 \\
19.0 \\
16.7\end{array}$ & $\begin{array}{r}6.3 \\
23.0 \\
65.1 \\
33.4\end{array}$ & $\begin{array}{l}77.0 \\
64.356 .5 \\
21.6 \\
54.7\end{array}$ & $\begin{array}{l}0.0 \\
0.0 \\
0.0 \\
0.0\end{array}$ & $\begin{array}{r}9.2 \\
12.17 .3 \\
1.5 \\
8.1\end{array}$ & $\begin{array}{r}2.1 \\
0.0 \\
11.8 \\
2.8\end{array}$ & \begin{tabular}{l}
55 \\
\hdashline$\ldots$ \\
0.0 \\
0.0 \\
1.0
\end{tabular} \\
\hline
\end{tabular}


of the Rogersburg I ocati on where fish was the mij or di et component. The percent of $\mathrm{fish}$ in the di et increased with snal I mouth bass size, and consumpti on of $\mathbf{j}$ uveni I e sal moni ds was seen pri mari l y i $\mathbf{n}$ I arge smal I mouth bass ( of the smal I mouth bass that i ngested sal noni ds, $90 \%$ were greater than $280 \mathrm{~mm}$ FL; Tabl e 11). However, overal I consumpti on rates of sal moni ds by smal I nouth bass were I ow $\left(x=0.01\right.$ salmonids $\left.\cdot \mathrm{fish}^{-1} \cdot \mathrm{day}^{-1}\right)$.

Stomach contents from other predators have not been processed and those data will be 'incl uded in next years' annual report.

Northern Squauf i sh Consumpti on I ndex

Consumpti on i ndex val ues at Snake Ri ver si tes ranged from zero at al I mid-reservoi r l ocati ons to 1.2 at Lower Granite Forebay (Table 12). In J ohn Day Reservoi $r$ spring CI val ues ranged from 0.5 at J ohn Day midreservoi r to 1.9 at J ohn Day For ebay, and 0.9 to 3.0 at the sane I ocations during the summer sampl ing peri od ( Table 12). Mean CI val ues generat ed from bootstrap anal yses were si milar to actual CI val ues as expected. Coeffici ents of vari ati on (CV) of the mean CIs were i nversel y rel ated to sample si ze and ranged from II \%65\% ( $x=23 \%$ at Snake Ri ver I ocati ons and $12 \%-90 \%$ at J ohn Day Reservoi r l ocati ons (Table 12).

In the Snake Ri ver, CI val ues for northern squauf $i$ sh col l ected were hi ghest in forebay and tai I race areas (Table 12), and were slight l y hi gher for fish collected i n restricted than in non-restricted zones (Tables 13 and 14). A I mid-reservoi $r$ I ocati ons had CI val ues for northern squaufi sh of 0 ( $i$. e. no sal moni ds were found i n di gesti ve tracts exami ned). Al so, CI val ues for northern squaufi sh were moderate $(0.3-0.8)$ at the four I ocati ons above Lower Granite mid-reservoi $r$ where high numbers of northern squaufish were capt ured. 
Tabl e 11. Prey fi sh consuned by smal I nouth bass (SMB) in reservoi $r$ - wi de areas (i ncl udi ng BRZs) in the I ower Snake Ri ver and J ohn Day Reservoi $r$ of the Col unbi a Ri ver duri ng 1990. See Table 5 for expl anati on of col ums.

PREY FI SH CONSUMED

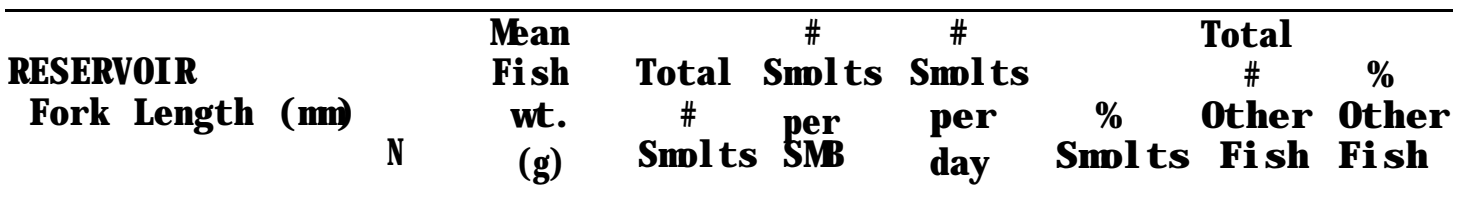

SNAKE R VER

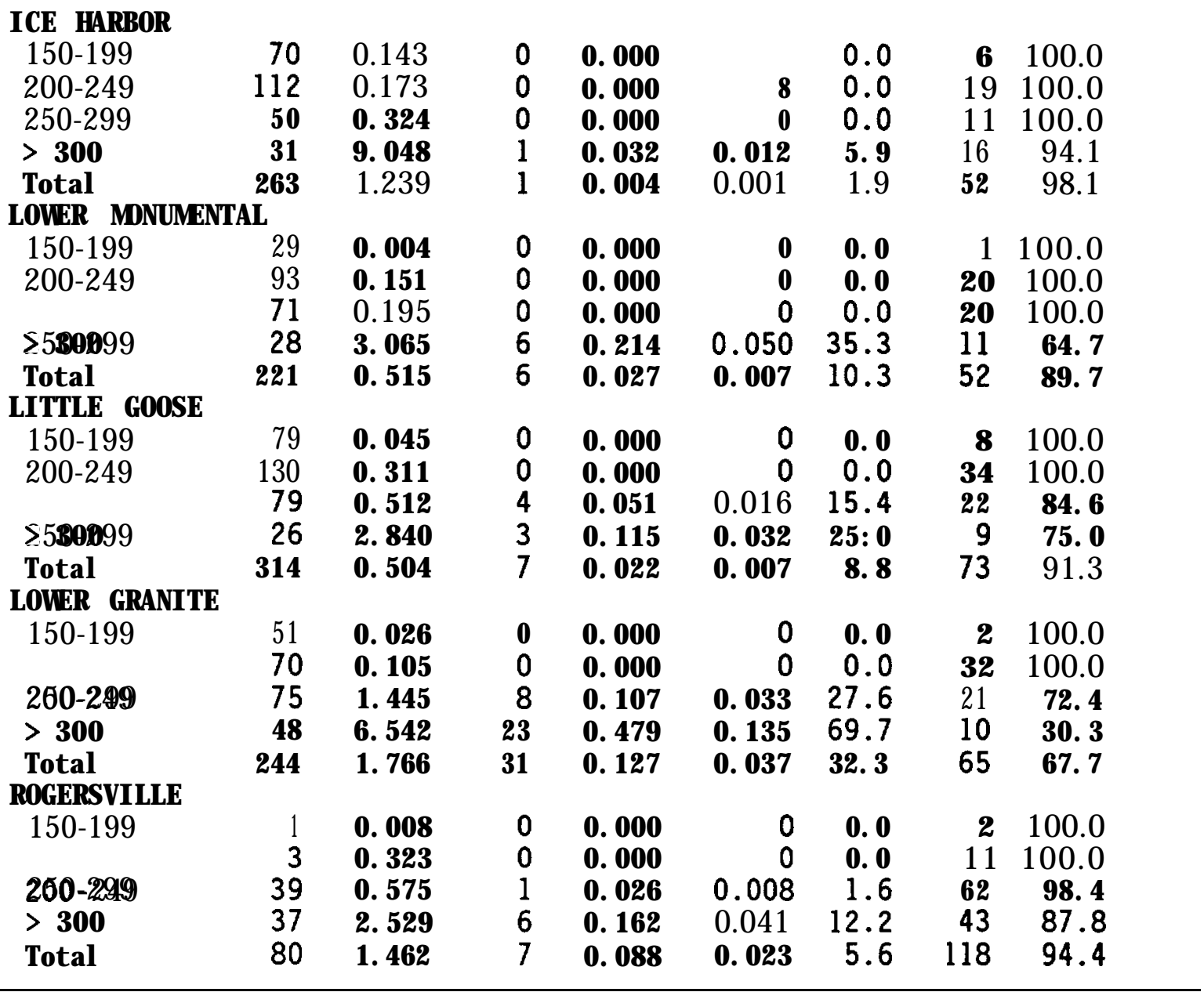


Tabl e 11. conti nued.

\begin{tabular}{|c|c|c|c|c|c|c|c|c|}
\hline \multirow[b]{2}{*}{$\begin{array}{l}\text { RESERVO R } \\
\text { Fork Length }(\mathrm{mm})\end{array}$} & \multirow[b]{2}{*}{$\mathrm{N}$} & \multicolumn{6}{|c|}{ PREY FI SH CONSUMED } & \multirow[b]{2}{*}{$\begin{array}{c}\% \\
\text { Other } \\
\text { Fi sh }\end{array}$} \\
\hline & & $\begin{array}{c}\text { Mean } \\
\text { Fi sh } \\
\text { ut. } \\
\text { (g) }\end{array}$ & $\begin{array}{c}\text { Total } \\
\# \\
\text { Snol ts }\end{array}$ & $\begin{array}{c}\# \\
\text { Smol ts } \\
\text { per } \\
\text { SMB }\end{array}$ & $\begin{array}{c}\# \\
\text { Snol ts } \\
\text { per } \\
\text { day }\end{array}$ & $\begin{array}{c}\% \\
\text { Snol ts }\end{array}$ & $\begin{array}{c}\text { Total } \\
\# \\
\text { Oher } \\
\text { s Fi sh }\end{array}$ & \\
\hline \multicolumn{9}{|l|}{ COLUMBIA RIVER } \\
\hline $\begin{array}{c}\text { J OFN DAY } \\
\text { A Spri ng } \\
150-199 \\
200-249 \\
\mathbf{2 5 0 - 2 9 9} \\
>\mathbf{3 0 0} \\
\text { Total }\end{array}$ & $\begin{array}{r}14 \\
36 \\
19 \\
9 \\
80\end{array}$ & $\begin{array}{l}\mathbf{0 . 0 2 4} \\
0.661 \\
\mathbf{0 . 5 6 3} \\
\mathbf{3 . 4 3 3} \\
1.011\end{array}$ & $\begin{array}{l}8 \\
\mathbf{0} \\
8\end{array}$ & $\begin{array}{l}\mathbf{0 . 0 0 0} \\
0.000 \\
\mathbf{0 . 0 0 0} \\
\mathbf{0 . 0 0 0} \\
0.000\end{array}$ & $\begin{array}{l}\mathbf{0} \\
8 \\
0 \\
0\end{array}$ & $\begin{array}{l}0.0 \\
0.0 \\
0.0 \\
0.0\end{array}$ & $\begin{array}{r}1 \\
11 \\
4 \\
5 \\
22\end{array}$ & $\begin{array}{l}100.0 \\
100.0 \\
100.0 \\
100.0 \\
100.0\end{array}$ \\
\hline $\begin{array}{l}\text { B. Summer } \\
150-199 \\
200-249 \\
\mathbf{2 5 0 - 2 9 9} \\
>\mathbf{3 0 0} \\
\text { Total }\end{array}$ & $\begin{array}{l}12 \\
37 \\
26 \\
21 \\
96\end{array}$ & $\begin{array}{l}\mathbf{0 .} \mathbf{0 6 7} \\
\mathbf{0 . 8 7 7} \\
1.091 \\
\mathbf{6 . 1 3 7} \\
1.984\end{array}$ & $\begin{array}{r}0 \\
3 \\
8 \\
11\end{array}$ & $\begin{array}{l}0.000 \\
0.115 \\
0.381 \\
0.381\end{array}$ & $\begin{array}{r}0 \\
22 ; \\
0.2 \% \\
0.200 \\
0.106\end{array}$ & $\begin{array}{r}0.0 \\
21.4 \\
36.4 \\
23.4\end{array}$ & $\begin{array}{r}1 \\
10 \\
\mathbf{1 4} \\
\mathbf{3 6}\end{array}$ & $\begin{array}{r}100.0 \\
100.0 \\
\mathbf{7 8 .} \\
\mathbf{6 3 . 6} \\
\mathbf{7 6 . 6}\end{array}$ \\
\hline
\end{tabular}


Tabl e 12. Northern Squauf i sh consumpti on i ndi ces ( Cl ) at I ocati ons i n the Snake, C earuater, and Col umbi a rivers during 1991. Nbte that a si ngl e 0 neans no $\mathbf{j}$ uveni l e sal moni ds were found i $n$ the predat or di gesti ve tracts. CI i s the consumpt i on i ndex for the ori gi nal sampl e ( $\mathrm{N}$ ). Mean CI, st andard devi ation (SD), coeffici ent of variation, (CV, $\%$ and quartiles are gi ven for the 500 bootstrap sampl es. Tr=Tai I race, $F b=f o r e b a y, ~ M r=M d-r$ reservoi $r$, Up=Upper.

\begin{tabular}{|c|c|c|c|c|c|c|c|c|}
\hline \multirow{3}{*}{$\begin{array}{l}\text { RESERVO R } \\
\text { Locat i on }\end{array}$} & & \multirow{3}{*}{$\mathbf{N}$} & \multirow{3}{*}{$\mathrm{CI}$} & \multicolumn{5}{|c|}{ Boot strap Summarv } \\
\hline & & & & \multirow{3}{*}{ Mean } & \multirow{3}{*}{ SD } & \multirow{3}{*}{$\mathrm{CV} \%$} & \multicolumn{2}{|c|}{ Quartiles } \\
\hline & & & & & & & $25 \mathrm{th}$ & $75 \mathrm{th}$ \\
\hline \multicolumn{6}{|l|}{ Snake Ri ver } & & & \\
\hline \multicolumn{9}{|l|}{ I CE HARBOR } \\
\hline Ice Har bor & $\mathbf{F b}$ & 5 & 0 & & 00 & -- & 0 & 0 \\
\hline Ice Har bor & $\mathbf{M}$ & 16 & 0 & 0 & 0 & -- & 0 & 0 \\
\hline $\begin{array}{l}\text { Lower Monumental } \\
\text { LOVER MONUMENTAL }\end{array}$ & $\mathrm{Tr}$ & $\begin{array}{l}80 \\
31\end{array}$ & 0.8 & 0.8 & 0.2 & 19 & 0.7 & 0.9 \\
\hline Lower Mbnumental & $\mathbf{F b}$ & 104 & 0.2 & 0.2 & 0.2 & 65 & 0.1 & 0.3 \\
\hline $\begin{array}{l}\text { Lower Monumental } \\
\text { Li ttl e Goose } \\
\text { LI TTLE GoOsE }\end{array}$ & $\underset{\mathbf{T r}}{\mathrm{Mr}}$ & 186 & 0.9 & $\begin{array}{r}0 \\
0.7\end{array}$ & $\begin{array}{r}0 \\
0.1\end{array}$ & $\overline{21}$ & $\begin{array}{r}0 \\
0.6\end{array}$ & $\begin{array}{r}0 \\
0.8\end{array}$ \\
\hline Little Goose & $\mathbf{F b}$ & 84 & 1.0 & 0.9 & 0.1 & 14 & 0.9 & 1.0 \\
\hline Little Goose & $\mathbf{M}$ & 16 & 0 & 0 & 0 & -- & & 0 \\
\hline $\begin{array}{l}\text { Lower Grani te } \\
\text { LOVER GRAN TE }\end{array}$ & Tr & 191 & 1.0 & 1.0 & 0.1 & 12 & 1.8 & 1.1 \\
\hline Lower Grani te & $\mathbf{F b}$ & 59 & 1.2 & 1.2 & 0.1 & 11 & 1.1 & 1.3 \\
\hline Lower Grani te & $\mathbf{M}$ & 5 & 0 & 0 & 0 & & 0 & 0 \\
\hline Lower Grani te & Up & 127 & 0.3 & 0.3 & 0.1 & 28 & 0.3 & 0.4 \\
\hline Asoti n & & 164 & 0.8 & 0.8 & 0.1 & 16 & 0.7 & 0.9 \\
\hline $\begin{array}{cl}\text { Cl ear wat er } & R i \text { ver } \\
\text { FREEFLOW NG } & \text { RI VER }\end{array}$ & & 183 & 0.6 & 0.6 & 0.1 & 17 & 0.5 & 0.7 \\
\hline Roger sburg & & 146 & 0.8 & 0.8 & 0.1 & 14 & 0.7 & 0.8 \\
\hline \multicolumn{9}{|l|}{ Col unbi a Ri ver } \\
\hline \multicolumn{9}{|l|}{$\begin{array}{l}\text { J OHN DAY } \\
\text { A SPRI NG }\end{array}$} \\
\hline MeNary & $\operatorname{Tr}$ & 82 & 1.4 & 1.4 & 0.2 & 12 & 1.3 & 1.6 \\
\hline John Day & $\mathbf{M r}$ & 6 & 0.5 & 0.5 & 0.4 & 90 & 0 & 0.9 \\
\hline John Day & $\mathbf{F b}$ & 23 & 1.9 & 2.0 & 0.3 & 15 & 1.8 & 2.2 \\
\hline \multicolumn{9}{|l|}{ B. SUMMER } \\
\hline MeNary & $\operatorname{Tr}$ & 96 & 2.4 & 2.3 & 0.6 & 28 & 1.8 & 2.7 \\
\hline John Day & $\mathbf{M r}$ & 6 & 0.9 & 0.8 & 0.6 & 82 & & 1.3 \\
\hline John Day & $\mathbf{F b}$ & 18 & 3.0 & 3.0 & 0.9 & 32 & 2.30 & 3.6 \\
\hline
\end{tabular}


Tabl e 13. Consumpti on i ndi ces ( $\mathrm{Cl}$ ) of northern squauf i sh wi thi $\mathbf{n}$ dam BRZs i $n$ the Snake, Cl earuater, and Col unbi a Ri vers during 1991. See Table 12 for expl anati on of col ums.

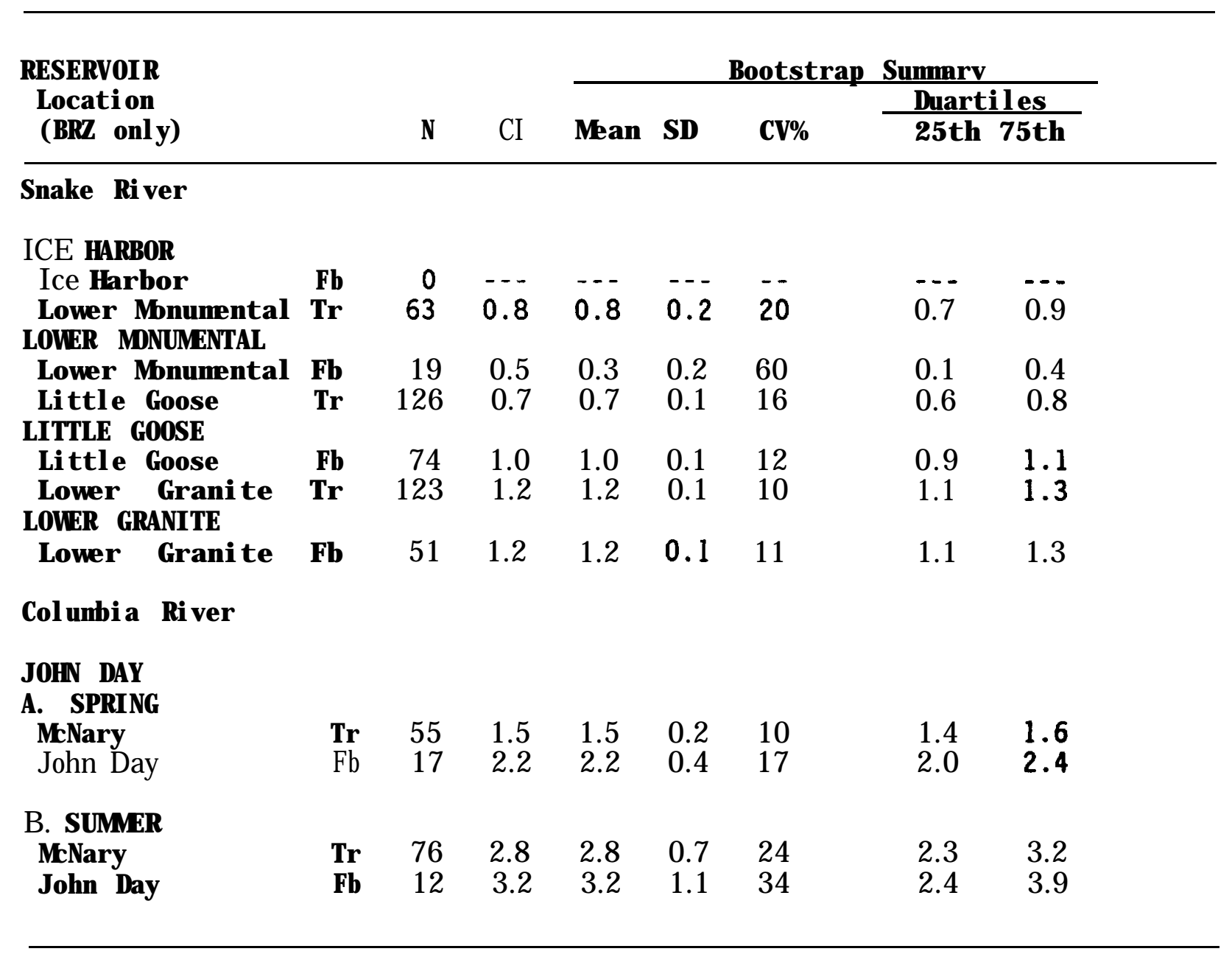


Table 14. Reservoi $r$ - wi de (excl udi ng BRZs at dans) Cls of northern squauf i sh duri ng the 1991 sampl ing in the I ower Snake and Col unbi a Ri vers. See Table 12 for expl anati on of col ums.

RESERVO $\mathbf{R}$

(excluding BRZs)

Snake Ri ver

I CE HARBOR

LDIEBE MESDEENTAL

LOVER GRAN TE

Col unbi a Ri ver

SPR NG

JOHN DAY

SUMMER

JOHN DAY
$38 \quad 0.4$

0.6

$946 \quad 0.6$

488

$36 \quad 0.9$

1.0

$0.3 \quad 36$

0.8

1.1

$31 \quad 0.7$

$\begin{array}{lll}0.4 & 67 & 0.3\end{array}$

0.9 
Reservoi $r$-wi de (i.e. areas not i ncl uding BRZs) Ols for northern squaufi sh ranged from 0.6 at Lower Grani te and Little Goose reservoi rs to 0.3 at Lower Mnumental (Table 14).

Bi oenergeti c Model ing

Mean wei ght of northern squaufi sh i ncreased si gni fi cantl y bet ween Myy and Septenber onl $y$ for the two age groups $\measuredangle$ and 6 yrs; these groups al so had the I argest sampl e si zes (Table 15). Fi sh 5 and 6 yrs ol d showed the Iargest percent age wei ght change during the grouth season ( $36 \%$ and $24 \%$ respecti vel y). Fish 7 yrs old increased $69 \mathrm{~g}$, but this change was not significantly different from zero. Mean wei ght of ol der $(8,>9 \mathrm{yrs}) \mathrm{fi}$ sh decl i ned, al though these wei ght I osses were not si gni fi cantly different fromzero and sample si zes were rel ati vel y small. The coefficients of variation (CV) were slightly hi gher during the spring than during the fall. Coefficients of variation declined with increasing age of $\mathrm{fi}$ sh during the fal $\mathrm{I}$, suggesting less wei ght variability in the ol der age groups.

Changes in mean fi sh wei ghts suggest that onl y younger i ndi vi dual s showed si gni fi cant posi ti ve grouth during the sumer in Bonneville midreservoi $r$; ol der fish di d not gai $n$ wei ght during the spring and sumer. Such a concl usi on is possi ble, meaning ol der fi sh were si mpl y feeding at a mai ntenance level during this period. Non-growing fish might still be consuming a si gnificant number of snol ts.

Age and grouth resul ts from 1990 were used to esti mate the ni ni mum sample sizes of aged northern squaufi sh needed in fut ure bi oenergetic studies to determine if the age and grouth procedure was feasible at several l ocations, or if sampling requi renents nould be too great. Because of the 
Tabl e 15. Mea nei gnt (g) and Coef $\mathrm{f} i \mathrm{ci}$ ent of Vari ati on ( CV as $9 / \mathrm{g}$ of northern squauf i sh col lected at Bonnevi l le mid-reservoi $r$ during Spring (My) and Fal I (Septenber) 1990. Change in wei ght bet ween spring and fal I is shown as the "Difference" (g). The probability that the difference was 0 is shown beneath $P$ (t-tests).

\begin{tabular}{|c|c|c|c|c|c|c|c|c|}
\hline \multirow[b]{2}{*}{ Age } & \multirow[b]{2}{*}{$\mathbf{N}$} & \multicolumn{3}{|c|}{ Spring } & \multicolumn{3}{|c|}{ Fal I } & \multirow[b]{2}{*}{$\mathbf{P}$} \\
\hline & & $\begin{array}{c}\text { Mean } \\
\text { Wei ght }\end{array}$ & $\mathbf{C V}$ & $\mathbf{N}$ & $\begin{array}{l}\text { Mean } \\
\text { Wei ght }\end{array}$ & $\mathbf{C V}$ & Difference & \\
\hline $\begin{array}{r}25 \\
6 \\
7 \\
8 \\
9 \\
>9\end{array}$ & $\begin{array}{r}8 \\
17 \\
4 \\
4 \\
6 \\
5\end{array}$ & $\begin{array}{r}290 \\
395 \\
\\
585778 \\
1015 \\
1146\end{array}$ & $\begin{array}{l}17 \\
28 \\
41 \\
31 \\
25 \\
33\end{array}$ & $\begin{array}{r}8 \\
14 \\
\mathbf{5} \\
6 \\
5 \\
3\end{array}$ & $\begin{array}{r}395 \\
489 \\
\\
654671 \\
1014 \\
980\end{array}$ & $\begin{array}{r}24 \\
23 \\
17 \\
13 \\
8 \\
8\end{array}$ & $\begin{array}{r}105 \\
94 \\
69 \\
-107 \\
-\quad 1 \\
-166\end{array}$ & $\begin{array}{r}.01 \\
.03 \\
\\
.34 \\
.99 \\
.50\end{array}$ \\
\hline $\begin{array}{l}\leq 6 \\
7-8 \\
\geq 9\end{array}$ & $\begin{array}{r}25 \\
8 \\
11\end{array}$ & $\begin{array}{r}362 \\
681 \\
1075\end{array}$ & $\begin{array}{l}29 \\
36 \\
\\
29\end{array}$ & $\begin{array}{r}22 \\
11 \\
8\end{array}$ & $\begin{array}{r}455 \\
664 \\
1001\end{array}$ & $\begin{array}{r}25 \\
14 \\
7\end{array}$ & & \\
\hline
\end{tabular}


rel at i vel y snal I numbers of northern squauf $i$ sh aged, we I umped fi sh i nt o three age- groups: $\leq 6,7-8$, and $\geq 9$ years of age (Table 15). Mean and standard devi ati on of each age-group in the spring uere used to esti mate sample si zes needed to detect wei ght change of $10 \%$ to $40 \%$ (Fi gure 6 ). The percentage wei ght changes that were tested spanned the observed seasonal grouth of 5-9 year-ol d northern squaufi sh i n Bonnevi I l e Reservoi r (Table 15), and such grouth might be expected el sewhere.

Detecting a rel ati vel y smal I change in grouth $(+10 \%)$ woul d requi re qui te I arge numbers $(>80)$ of northern squauf $\mathrm{i}$ sh to be caught and aged i $n$ each agegroup ( Fi gure 6). Larger percentages of grouth ( $>20 \%$ ) woul d requi re consi derabl y fewer aged i ndi vi dual s $(<20)$. The seasonal changes in wei ght we observed for northern squauf i sh i n the Bonnevi I l e mid-reservoi $\mathbf{r}$ I ocati on were

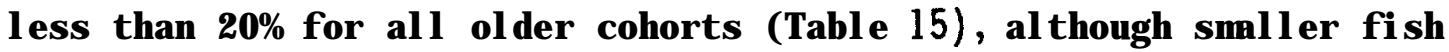
general Iy added more than $20 \%$ of thei $r$ body weight during the spring to fal I peri od (Tablle 15). These concl usi ons about sampl e si ze are si milar to those of Petersen et al. (1990).

Us ing 1983-86 data from J ohn Day Reservoi r, mean predat or wei ght renai ned constant or decl i ned sl i ghtl y i n MtNary tai I race BRZ bet ween Apri I and J une; onl y i n 1984 di d mean wei ght i ncrease sl i ghtl y during thi s peri od (Fi gure 7). In 1985 and 1986, mean wei ght decl i ned consi derabl y from J une to J ul y, probabl y because of spawning I osses (U. S. Fi sh and Vil dl i fe Servi ce, unpubl i shed data). Mean predat or wei ght showed a smal I i ncrease fromJ ul y to August where data were avai I abl e (1985, 1986).

In the J ohn Day pool, mean predat or wei ght was si gni fi cant l y I ess than the wei ght of predat ors capt ured i n MtNary tai I race BRZ ( Fi gure 7), but wi thi $\mathrm{n}$-year trends were si milar. For al l years, the nean predat or wei ght 


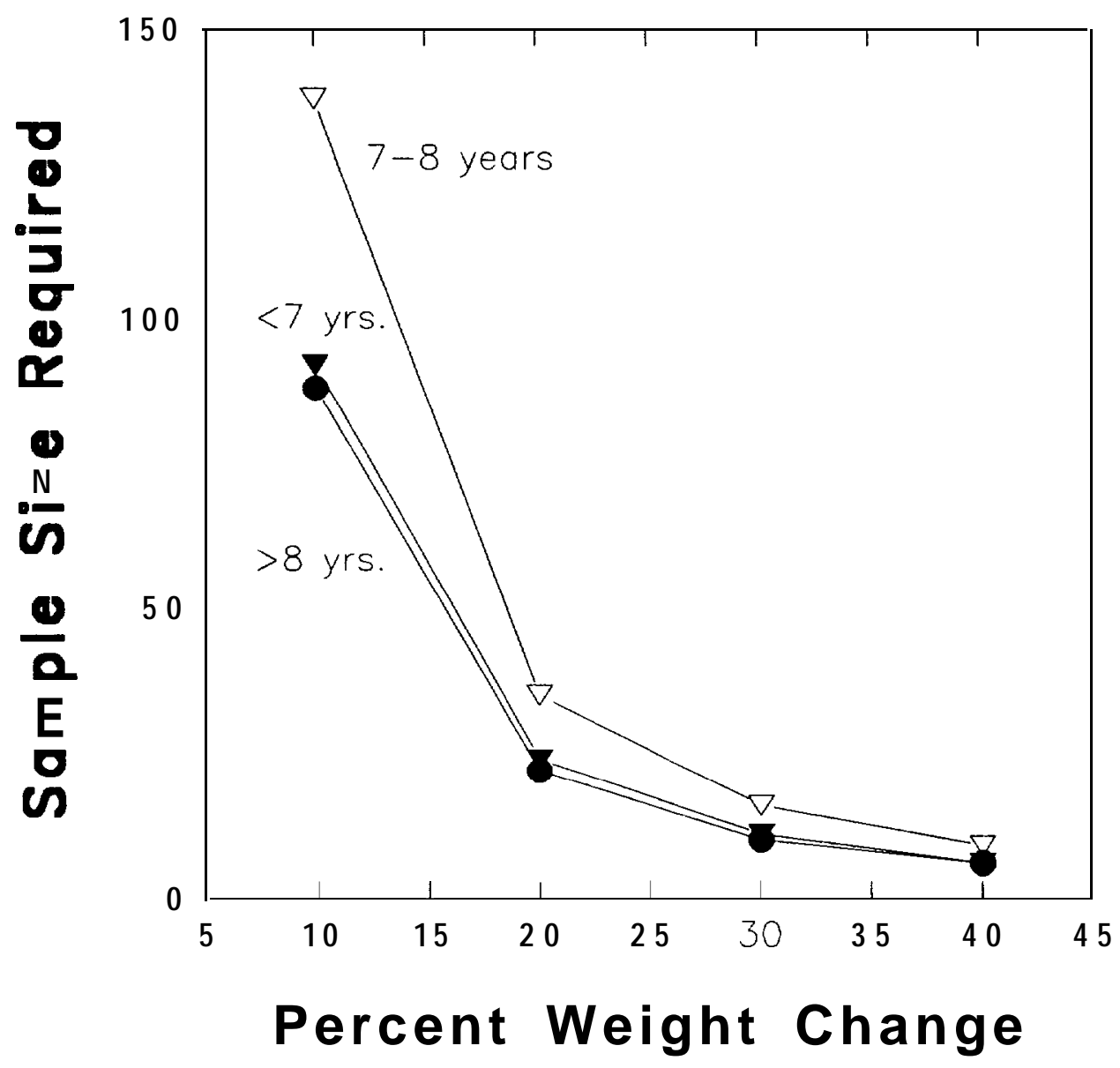

Figure 6. Number of aged northern squawfish required to detect a percentage weight change. 

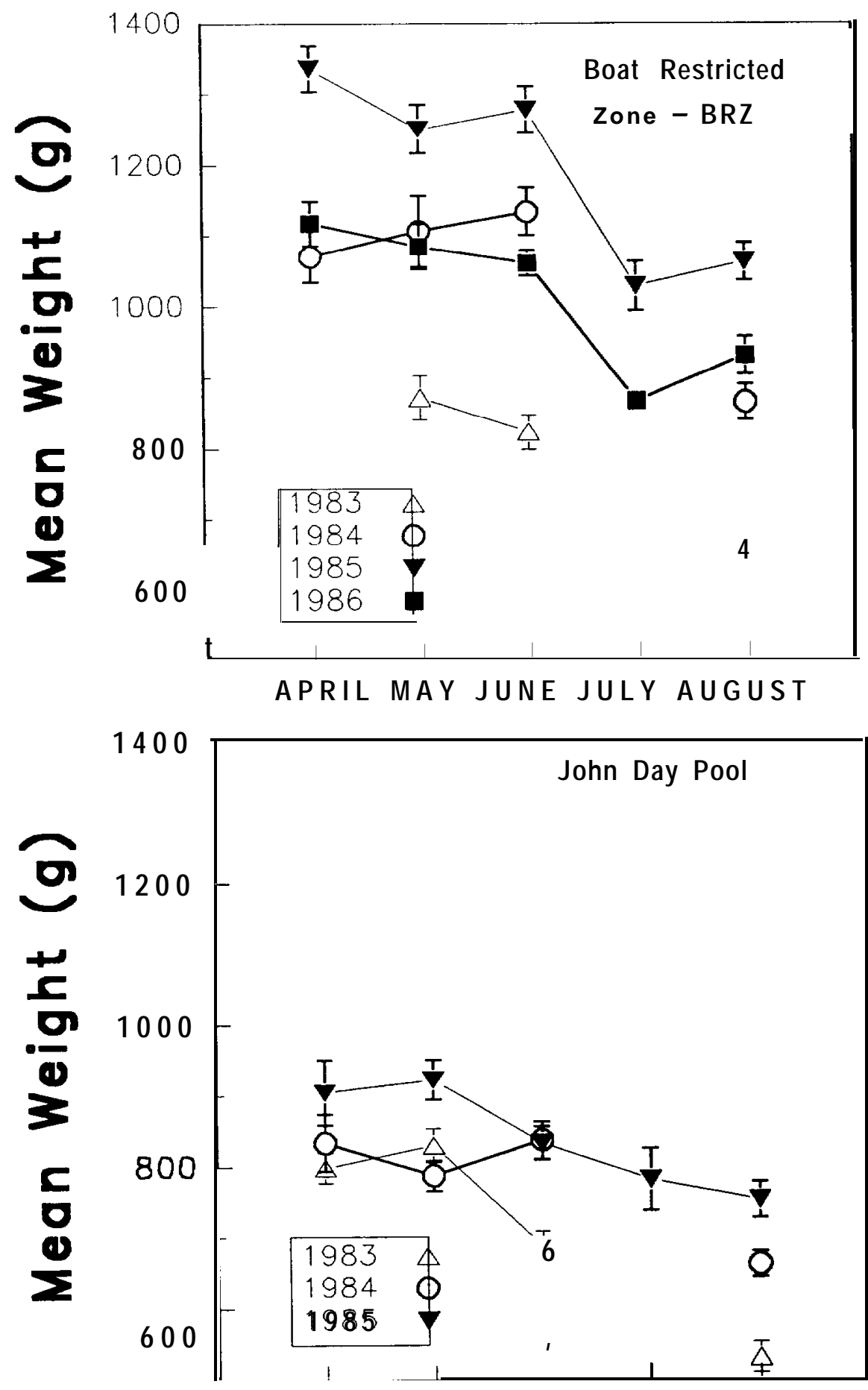

APRIL MAY JUNE JULYAUGUST

Figure 7. Mean monthly weight of northern squawfish from MCNary Dam BRZ and John Day pool (1983-1986). 
gradual ly declined during April to August in the pool. Northern squaufish di d not show any increase in wei ght during the late summer as was observed in the BRZ, al though onl y one year's data (1985) were avai I able from the reservoi $r$ for this period. 


\section{DISCUSSION}

According to Petersen et al. (1991), the goal of predati on i ndexing is "to provi de a ranking of l ocations and reservoi rs throughout the Col unbi a Ri ver basi $n$ according to the i ntensity of predati on upon $\mathbf{j}$ uveni l e sal moni ds. " As part of the study design, John Day Reservoi $r$ was to be sampl ed every year to provi de data on inter-annual trends. Due to the I ow water temperatures encount ered whi I e sampl ing Snake Ri ver I ocati ons (range 6-13 $\mathrm{C}$ ) any compari sons to Col unbi a Ri ver I ocati ons shoul d be nade with data fromthe spri ng sampl ing peri od (1990 water temper at ure range $\left.10-13^{\circ} \mathrm{C} ; 199111.5-13^{\circ} \mathrm{C}\right)$.

Northern squaufi sh CIs for Snake Ri ver I ocati ons were hi ghest around hydroel ectric projects and l owest at mid-reservoi r l ocati ons. The same trend was observed i n 1990 for I ower Col umbi a Ri ver reservoi rs (Petersen et al 1991; Appendi $x$ A). However, the rel at i ve mani tude of predati on at Snake Ri ver I ocati ons was I ower ( $\mathrm{x} C \mathrm{C}=0.5$, range 0.1 .2 ) than at I ower Col umbi a Ri ver I ocati ons in the spring ( $1990 \times \mathrm{CI}=1.3$, range 0.4. 8; $1991 \times \mathrm{CI}=1.3,0.5-1.9)$ even though the nean number of sal moni ds per northern squauf ish were not

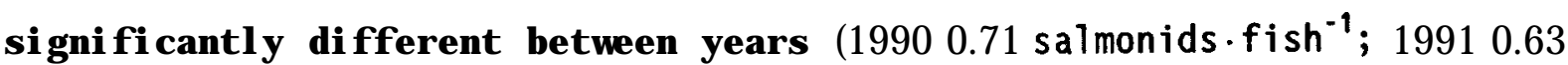
salmonids.fish $\left.{ }^{-1} ; P=0.35\right)$. We offer several possi bl explanations for the I ower CIs. Fi rst, water temperatures were I ower at Snake Ri ver I ocati ons than Col umbi a Ri ver l ocati ons i n spring, whi ch woul d resul t in sl ower evacuati on rates by northern squaufi sh (Beyer et al. 1988). Second, I arge numbers of sal moni ds are bypassed and transported from Lower Granite and Li ttl e Goose dans; thus fewer sal moni ds my have been avai I able to northern squaufish. A so, the mean si ze of northern squauf $i$ sh capt ured at Snake Ri ver I ocations was about $10 \%$ snal ler than fi sh captured i n J ohn Day Reservoi r. Vi gg et al. (1991) reported that I arger northern squauf $\mathrm{i}$ sh had the hi ghest consumpti on 
rates on juveni l e sal moni ds; ther ef ore, the smal l er si ze of fi sh capt ured may contri bute to the I ower CIs observed. Al though CI val ues were zero (i.e. no sal noni ds vere found i n northern squaufi sh di gesti ve tracts) for al I Snake Ri ver mid-reservoi $r$ si tes, it is unl i kel y that northern squauf i sh do not consume any $\mathbf{j}$ uveni l e sal noni ds i $\mathbf{n}$ these l ocati ons based on data from J ohn Day Reservoi r (Poe et al. 1991).

A though we di d not col l ect the predetermi ned dai l y mi mum sampl e si zes of northern squauf $\mathrm{i}$ sh at 7 of 15 l ocations, we bel i eve in nost areas our CI results are still valid for two reasons. The predetermined daily sample sizes were based on data from J ohn Day Reservoi r (Petersen et al. 1990). However, coef $i$ ci ents of variati on of the mean CIs at Snake Ri ver I ocati ons were I ower ( $\mathrm{C}$ CV=23\%) than at Col unbi a Ri ver I ocati ons in 1990 ( $\mathrm{CV}=43 \%)$ i ndi cati ng the the anount of sal moni ds in the di et of northern squauf $\mathrm{i}$ sh was less vari able at Snake River I ocations. We al so perforned pai $r$-wise tests of hypothetical compari sons of $\mathrm{CI}$ val ues (CI vs. $\mathrm{CI} / 2$, and $\mathrm{CI}$ vs. $\mathrm{CI} * 2$ ) from I ocati ons where ue di d not achi eve our mi mim sample si ze and determi ned the statistical power (1- $\beta$; probability of a type II error, $\alpha=0.05)$ of the tests. Average power was $>99 \%$ at al I I ocations except at J ohn Day mid-reservoi $\mathbf{r}$ where average power was $42 \%$ for $\mathrm{CI}$ vs. $\mathrm{CI} / 2$ and $88 \%$ f or $\mathrm{CI}$ vs. CI*2.

We tried to coordi nate sampling at Snake Ri ver I ocations with hatchery rel eases and hi stori c passage of $\mathrm{j}$ uvenile sal noni ds at dam l ocati ons, parti cul arly spring chi nook sal mon ( Onchorvnchus tschawutscha) because of thei $r$ suscepti bi I ity to predati on by northern squauf i sh (Poe et al. 1991). In general, ti ming of sampl i ng coi nci ded wi th i ncreased numbers of sal noni ds at most I ocati ons except at Lower Mbnumental Dam where CI val ues were I ow (F i gure 8). Of i nteresting note, we sampl ed at the Clearwater Ri ver 12 h after a 

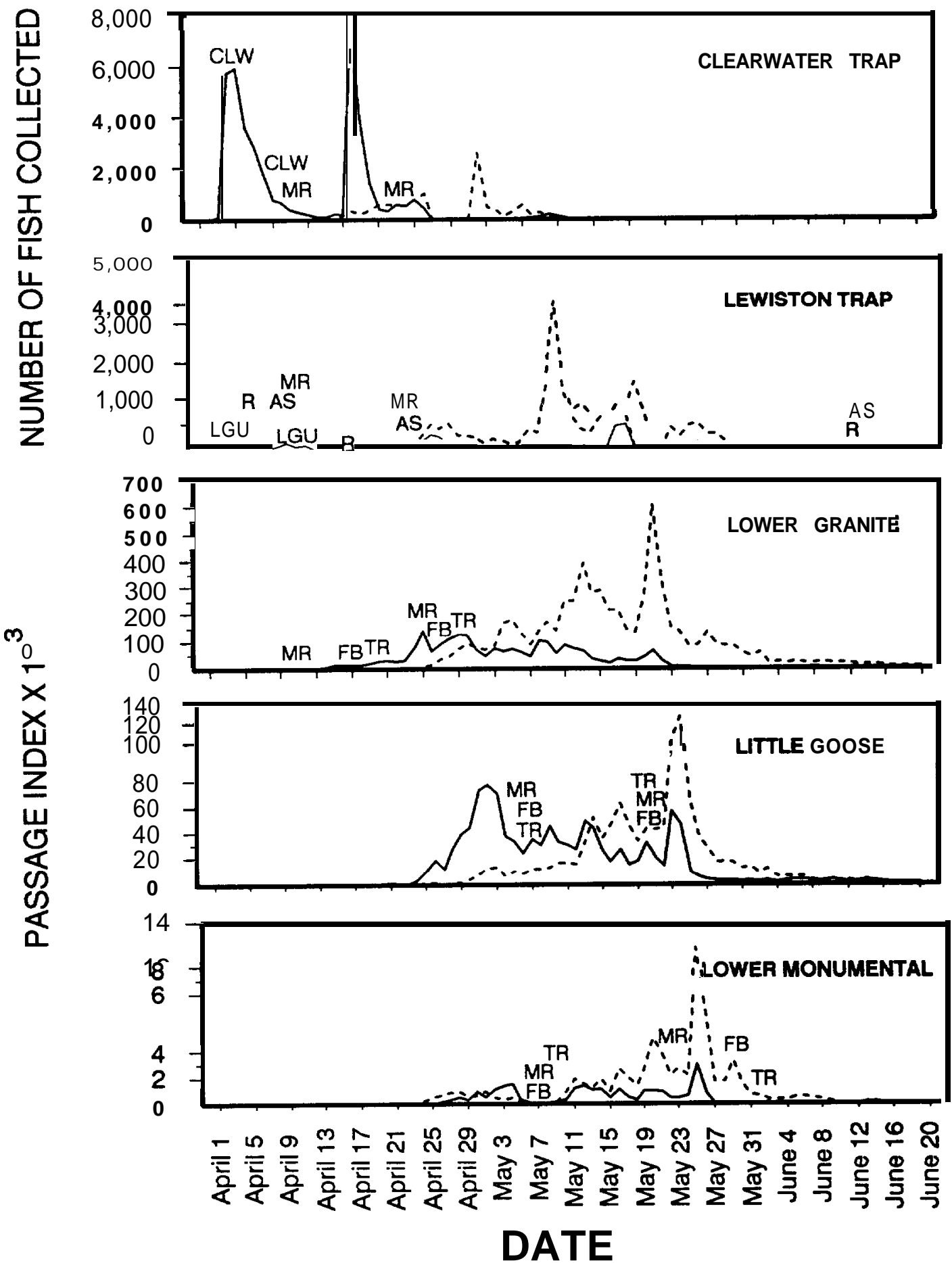

Figure 8. Timing of consumption index sampling at Snake River locations with respect to spring chinook (solid line) and steelhead (dotted line) passage indices at mainstem dams and trap facilities. Approximate sample times for tailrace (TR), forebay (FB), Upper-reservoir (UP), immediate downstream midreservoir (MR), and other locations are shown in a panel. The MR location in the Lower Granite panel, for example, actually represents sampling at Little Goose mid-reservoir location. Passage data from the Fish Passage Center, 1991. 
rel ease of about $1 \mathrm{mili}$ on spring chi nook sal non from Duorshak Nati onal Fi sh Hatchery and despi te the I ow water temperat ures $\left(6^{\circ} \mathrm{C}\right)$ northern squawf i sh cont ai ned an average of $\mathbf{0 . 8 5}$ sal moni ds. fi sh-' . Sampl ing i $\mathbf{n}$ John Day reservoi $\mathbf{r}$ al so coi nci ded wi th hi gh passage of j uveni l e sal moni ds at MtNary and J ohn Day dans ( Fi gure 9).

Catches of northern squaufi sh were hi ghest in BRZs si milar to previ ous years (Petersen et al. 1990, 1991). A so, rel ati vel y hi gh numbers of northern squauf i sh were capt ured in the upper I ocati ons of Lover Grani te reservoi $r$ and the free-fl owing Rogersburg I ocation (Table 1). Sampling of these I ocati ons coi nci ded wi th hatchery rel eases from the Cl earuater, Sal mon, and Grande Ronde ri vers and it was possi bl e northern squaufi sh were congregating in these areas due to hi gh preyfi sh densities. However, CIs for northern squaufi sh were moderate (0.3-0.8) compared to other Snake Ri ver I ocations. Catches of northern squauf i sh (and ot her predat ors) al so i ncreased duri ng turbi d condi ti ons at several I ocati ons. Ki rkl and (1962) attributed i ncreased catch rates during hi gh turbi di ty to decreased vi sual acuity, which al I ows el ectrof i sher uni ts to approach cl oser wi thout detection by fi sh. Attenuated I i ght could al so pronote nocturnal feeding of certai $n$ fishes (e.g. i ctal urids) and cause them to move into shore to feed during the day (Mbyle and Cech 1988) or cause si ght-ori ented fi shes to move away from substrate (Gradell and Swenson 1982) possi bl y maki ng them more suscepti bl e to capt ure by el ectrof $i$ shi ng. Consumpti on i ndex val ues for northern squauf $i$ sh were I ower during the period of high turbidity. Zaret (1979) noted that si ght feeding predators exhi bit a decrease in feeding efficiency during periods of high turbi di ty, whi ch may account for the I ow CI val ues duri ng these condi ti ons. A so, shorter predat or reacti ve di stance to prey and fewer encount ers bet ween 


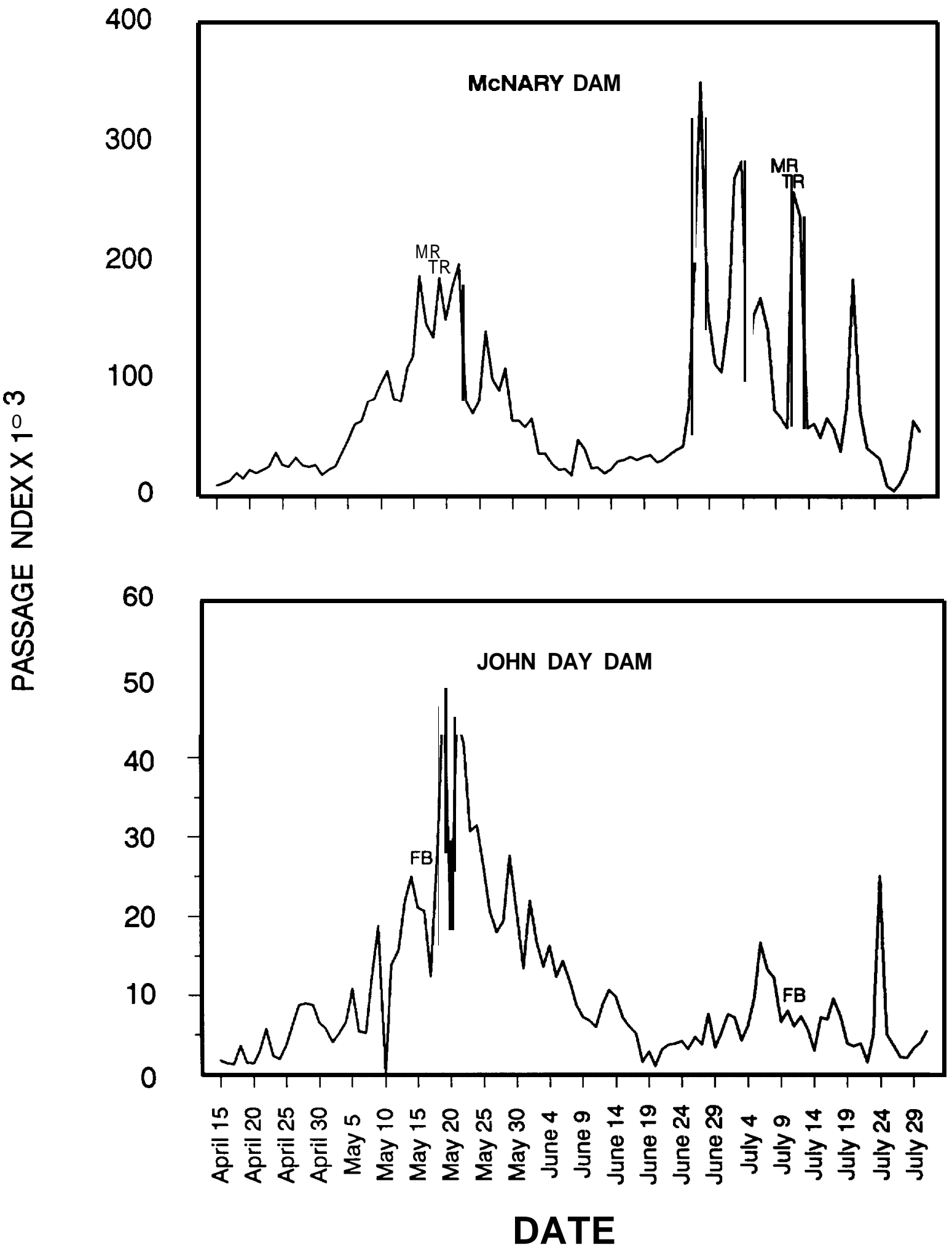

Figure 9. Timing of Consumption Index sampling during 1991 with respect to juvenile salmonid passage indices at John Day and McNary Dams. See Figure 8 for an explanation of notation. 
predator and prey coul d contri bute to a decrease in Cl val ues ( Vi nyard and O Bri en 1976).

Snal I mouth bass accounted for $41 \%$ of our total catch (Table 2 ). However, our data suggest the smal I nouth bass predati on on out-migrating sal noni ds was I ow Tabor et al. (MS) reported smal I nouth bass consumpti on rates to be rel ati vel y hi gh ( 0.9 to 1.3 salmonids $\left.\cdot \mathrm{fish}^{-1} \cdot \mathrm{day}^{-1}\right)$ on recentl y energed chi nook sal mon near the Hanf ord reach of the Col unbi a Ri ver. We est i nated smal I nouth bass mean consumpti on rate of sal moni ds to be mich I ower ( 0.01 salmonids. $\mathrm{fish}^{-1} \cdot \mathrm{day}^{-1}$ ) at Snake Ri ver I ocati ons. The I ower consumpti on rates at Snake River I ocations may be due to several factors: 1) the maj ority of sal moni ds migrating at the ti ne of our sampl i ng uere $\mathrm{j}$ uveni l e spring chi nook sal mon and steel head whi ch may not be as suscepti bl e as subyearl ing chi nook sal mon to predati on by smal I nouth bass due to si ze and habi tat sel ecti on; 2) water temperatures were I ower at Snake Ri ver I ocati ons than in the Hanf ord reach and ther ef ore smal I mouth bass my not be as acti vel y feeding and; 3) there could be a difference in prey densities and al ternative prey avai I able between the two areas.

Bi oenergeti c Mdel ing

Resul ts of the northern squaufi sh scal e anal yses suggest that I arge numbers (>50 per age group) of aged northern squauf i sh woul d be necessary to detect expected seasonal grouth in predators $\geq 9$ years; smal l er sampl es $(<20)$ woul d be needed to detect seasonal grouth in younger, fast-growing predators. Large sampl es nould be necessary to ensure that an adequate number of scal es were avai I abl e in each cohort. These concl usi ons prompted us to expl ore al ternative nethods for determining seasonal grouth of northern squaufish in 
reservoi rs, particularly the use of I ength or wei ght frequency di stributions.

An al ter nati ve method to determi ne age-specific grouth may be needed bef ore the northern squauf i sh bi oenergeti cs model can be appl i ed to broadscal e questions about consumption rate and I oss. An obvi ous approach to this probl em i s to use I ength or wei ght di stri buti ons and consi der how these di stri buti ons change through a season. Consumpti on has been shown to vary wi th wei ght ( Vigg et al. 1991; Petersen and DeAngelis, MБ), suggesti ng that si ze, rather than age, may be a better i ndi cator of potential feeding rate. A so, I ength or wei ght data are much easi er to gat her and noul d be avai l abl e f rom several sources (predati on i ndexi ng, dam angl ing, sport bounty fi shi ng, et c. ).

A typi cal uei ght di stri buti on from a northern squawf $i$ sh popul at $i$ on represents indi vi dual s of a broad age range, roughl y 4-15 years of age. Si zeat-age may vary greatl y so three i ndi vi dual s wi th the same wei ght might bel ong to three different age cohorts (Ri enan and Beanesderfer 1988). Cohort peaks cannot be di sti ngui shed in such a di stributi on because of vari able grouth rates and, perhaps, vari abl e spawni ng dates wi thi n a year (My to August or I ater). Tho approaches for usi ng si ze-frequency data are suggested bel ow 1) mean wei ght change for al sampled predators ( si milar to the "average predat or" concept used by Poe et al. (1991) and Vigg et al . (1991)); and 2) wei ght change of fractions of a size distribution by using percentiles.

Cochran and Knutsen (1988) showed the true mean rate of food i ntake can be accuratel y esti mated with a bi oenergeti c model usi ng changes i n mean body mass. They si mul at ed grouth of I argenouth bass ( $\mathrm{M}$ cropterus sal moi des) and compared predicted and observed rates of consumption. Mbdel-predicted consumpti on rates di ffered negl i gi bl y $(<3.5 \%)$ from actual rates i $n$ al I 
compari sons, except when extrene si ze-sel ecti ve nortal ity or gear bi as was i nt roduced. However, compari sons uere for a rel at i vel y narrow range of wei ghts - maxi mum range for thei $r$ "I arge" fi sh group was 160-240 g starti ng wei ght. Data from J ohn Day Reservoi r and MtNary tai I race i ndi cate that changes in nean wei ght can be detected by rel ati vel y smal l fi el d sampl es. Typi cal northern squauf i sh appear to I ose wei ght duri ng spring through earl y sumer and do not begi $n$ to gai $n$ wei ght unt $\mathrm{I}$ fal I, when water temperat ures are qui te high. These observed patterns of wei ght change general I y agree wi th earlier attempts to predict seasonal grouth using a bi oenergetic nodel ( Petersen et al. 1990).

Use of mean uei ghts for seasonal grouth anal ysi s requi res assumpti ons about normal ity of predat or sizes and the I ack of a si ze effect upon feedi ng rate. As might be expected, even I arge monthl y samples of fi sh from the ri ver are non- normally di stributed ( unpubli shed Fi sh and Vill dl ife Servi ce data). Other studi es have shown a si ze-rel ated feedi ng response, wi th I arger predators capabl e of eati ng many nore sal moni ds than smal I predators ( Vi gg et al. 1991; Petersen and DeAngel is, MS). Vi ol ati on of these assumpti ons suggests the need for a more refined anal ysi s of seasonal grouth.

An al ternati ve method for describi ng wei ght change woul d be to use the percentiles of frequency di stributions of wei ght and exami ne how these percentile markers shift over a period of ti me when we expect grouth. Equal I y-spaced percenti l es (e.g. , 10th, 20th, 30th . ...) woul d represent equalsi zed parts of a di stribution. Just as the nei ght of the average i ndi vi dual should i ncrease with ti ne, equi val ent percentiles should al so i ncrease toward I arger wei ghts, providing there was grouth in sone or al I of the population. Thi s approach woul d be most hel pf ul when si ze di stri buti ons change shape 
during a growing season, as when smal I predators grow much faster than I arge predators. The nonl $\mathrm{i}$ near rel at i onshi $\mathrm{p}$ bet ween si ze and predati on rate (Pet ersen and DeAngelis, Mb) could i nt eract wi th si ze-specific seasonal grouth to produce I osses not easi ly predi ctable usi ng a si ngl e si ze stati sti c, such as mean i ndi vi dual wei ght.

Several ( $n$ ) percentile "cohorts" could be nodeled and the predicted capt ure rate (salmonids $\cdot \mathrm{fish}^{-1} \cdot \mathrm{day}^{-1}$ ) coul d be esti mated for each representative percentile. The mean popul ati on capt ure rate woul d be the percenti l e capt ures sumed/ n; each percent i l e capt ure rate woul d represent an equal proportion of the popul ation as I ong as percentiles were equal I y spaced, so no wei ghting woul d be necessary.

Bi oenergeti c nodel ing work will proceed in three areas: 1) Paraneters for the northern squawf i sh model will be revi ewed and updated. In parti cul ar, recent l y esti nated respi rati on parameters for northern squaufi sh (Cech et al. Mb) will be incorporated into the nodel. 2) The possibility of using northern squauf i sh age- grouth i nf or mati on f rom ODFW and Whshi ngt on Depart ment of Vil dl ife ( VOW will be expl ored. ODFW and VOW pl an to age I arge numbers of northern squauf $\mathrm{i}$ sh during the coming years as part of the eval uati on of the predator removal program Sone of these data may be appropri ate for bi oenergeti c studies. 3) Methods for usi ng si ze-frequency di stri buti ons to esti mate seasonal grouth wi I be further devel oped and expl ored. Mbdel predi cted consumpti on rates wi l be compared to fi el d esti nates using the 1983-86 predator-prey data set. 


\section{REFERENCES}

Buchanan, D. V., R. M Hooton, and J.R. Mri ng. 1981. Northern squaufi sh ( Ptychochei I us oregonensi s) predati on on $\mathrm{j}$ uveni l e sal moni ds i $n$ sections of the Willanette Ri ver Basi $n$, Oregon. Canadi an J ournal of Fi sheri es and Aquati c Sci ences 38: 360-364.

Backi el, T. 1971. Production and food consumpti on of predatory fi sh in the Vi stul a Ri ver. J ournal of Fi sh Bi ol ogy 3: 369-405.

Beyer, J.M, G Lucchetti, and G Gray. 1988. Di gesti ve tract evacuati on i n nort hern squauf $i$ sh (Ptvchochei I us or eqonensi s). Canadi an J ournal of Fi sheri es and Aquatic Sci ences 45: 548- 553.

Cech, J.J. Jr., D. T. Cast l eberry, T. E. Hopki ns, and J . H Petersen. MS i n preparation. Northern squauf $i$ sh 0 , consumpti on rate: ef fects of temperature and body si ze.

Cochran, P. A, and K. J. Knutsen. 1988. Error i n esti mati on of feedi ng rates from changes i n mean body mass. Canadi an Journal of Fi sheri es and Aquati c Sci ences 45:1494-1498.

Fi ckei sen, D. H , D. D. Daubl e, and D. A Nei tzel. 1990. Proceedi ngs of the predat or-prey nodel ing norkshop. Bonnevill e Power Admi ni stration, Portl and, Oregon.

Gradal I, K. S. and WA Suenson. 1982. Responses of brook trout and creek chubs to turbi dity. Transactions of the American Fi sheries Soci ety III(3): 392-395.

Hansel, H. , S. D. Duke, P. T. Lof y, and G Gray. 1988. Use of di agnosti c bones to i dentify and esti mate origi nal l engths of i ngested prey fishes. Transacti ons of the Ameri can Fi sheri es Soci ety 117: 55- 62.

Henchman, T. R. 1986. Di stributi on and food habi ts of northern squaufi sh, Ptvchochei I us or esonensi s (Ri chardson), and esti mat es of thei $r$ consumpti on of migrating $\mathbf{j}$ uveni l e sal moni ds i $\mathbf{n}$ J ohn Day Reservoi $r$ and Tai I race duri ng the spri ng and sumer, 1983. Master's Thesi s, Uni versi ty of Whshi ngt on, Seattl e, Whshi ngt on.

K rkl and, L. 1962. A taggi ng experi ment on spotted and I argemouth bass usi ng an el ectric shocker and Peterson disc tag. Proceedi ngs of the Southeastern Associ ati on of Gane and Fi sh Comi ssi oners. 16: 424432.

Mbyl e, P. B. and J.J. Cech J r. 1988. Fi shes: an i nt roducti on to i cht hyol ogy. 2nd editi on. Prenti ce Hal I, Engl ewood Cl iffs, New Jersey, 559 pp.

N gro, A A (ed.) 1990. Devel opi ng a predati on i ndex and eval uati ng ways to reduce sal noni d I osses to predati on i $n$ the Col unbi a $\mathbf{R i}$ ver Basi $n$. Fi nal report of research, Bonnevill e Power Admi ni stration, 
Portl and, $\mathbf{O R}$.

Patten, B. C. 1960. A hi gh i nci dence of the hybri d Acrochei I us al utaceum $x$ Ptvchochei I us or eoonensi s. Copei a 1:71-73

Petersen, J.H, MG Mesa, J.Hall-Gri suol d, WC. Schrader, G. Short, and T.P. Poe. 1990. Magni tude and dynanics of predati on on $\mathbf{j}$ uveni l e sal noni ds i n Col unbi a and Snake Ri ver reservoi rs. Annual Report of Research, 1989-1990. Bonnevi Il e Power Admi ni stration, Portl and, Oregon.

Petersen, J.H , D. B. Jepsen, R. D. Nel I e, R. S. Shi vel y, R. A Tabor, and T. P. Poe. 1991. Syst em wi de si gni fi cance of predati on on $\mathrm{j}$ uveni l e sal noni ds i n Col unbi a and Snake Ri ver reservoi rs. Annual Report of Research, 1990. Bonnevi I l e Power Admi ni strati on, Portl and, Oregon.

Pet ersen, J.H and D. L. DeAngel i s. MS i n revi ew Predat i on by nort hern squauf i sh (Ptvchochei I us oresonensi s) on j uveni I e sal moni ds in the Col unbi a Ri ver: an i ndi vi dual-based nodel approach.

Poe, T. P., and B. E. Ri eman, edi tors. 1988. Predati on by resi dent fi sh on j uveni I e sal moni ds i n J ohn Day Reservoi r, 1983-86. Fi nal Report. Bonnevi I l e Power Admi ni strati on, Portl and. (Oregon)

Poe, T. P., H C. Hansel, S. Vi gg, D. E. Pal ner, and L. A Prendergast. 1991. Feedi ng of predaceous $f i$ shes on out-mi grati ng $j$ uveni $I$ e sal moni ds i n John Day reservoi r, Col unbi a Ri ver. Transacti ons of the Ameri can Fi sheri es Soci ety 120: 405- 420.

Ri eman, B. E. and R. C. Beanesderfer. 1988. Popul ati on dynamics of northern squauf $\mathrm{i}$ sh and potent $\mathrm{i}$ al predators on $\mathrm{j}$ uveni $\mathrm{l} e$ sal noni ds i $\mathrm{n}$ a Col unbi a Ri ver reservoi $r$. In Poe, T. P., and B. E. Ri enan, edi tors. 1988. Predati on by resi dent fi sh on $j$ uveni l e sal moni ds i n J ohn Day Reservoi r, 1983-86. Fi nal Report. Bonnevi II e Pouer Admi ni strati on, Portl and. (Oregon)

Ri enan, B. E. , R. C. Beamesderfer, S. Vi gg, and T. P. Poe. 1991. Est i nat ed I oss of $j$ uveni l e sal moni ds to predati on by northern squauf $i$ sh, ual l eyes, and smal I mouth bass i n J ohn Day reservoi $r$, Col umbi a Ri ver. Transacti ons of the the Aneri can Fi sheri es Soci ety. 120(4) : 448- 458.

Rogers, J.B. and C. C. Burl ey. 1991. A si gnoi d nodel to predi ct gastri c evacuati on rates of smal I mouth bass ( $M$ crooter us dol omeui) fed j uveni I e sal mon. Canadi an J ournal of Fi sheri es and Aquati c Sci ences 48: 933- 937.

Seaburg, K. G 1957. A stonach sampl er for I i ve fi sh. Progressi ve Fi sh Cul turi st $19: 137-139$.

Tabor, R. A, R. S. Shi vel y, and T. P. Poe. MS i n revi ew Predati on on j uveni I e 
sal noni ds by smal I nouth bass and northern squauf i sh in the Col umbi a Ri ver near Ri chl and, Whshi ngt on.

Vi gg, S. and C. C. Burl ey. 1990. Devel opi ng a predati on i ndex and eval uati ng uays to reduce $\mathrm{j}$ uveni I e sal moni $d$ I osses to predati on in the Col unbi a Ri ver Basi $n$. I n Devel opi ng a predati on i ndex and eval uati ng ways to reduce sal moni d I osses to predation in the Col unbi a Ri ver Basi n. A. A $\mathbf{N}$ gro edi tor. Annual report of research, 1990. Bonnevi I le Power Admi ni strati on, Portl and, Oregon.

Vigg, S., T. P. Poe, L. A Prendergast, and H C. Hansel . 1991. Rates of consumpt $i$ on of $j$ uveni I e sal noni ds and al ternati ve prey $f i$ sh by northern squauf i sh, wal I eyes, smal I mouth bass, and channel catfi sh i n J ohn Day Reservoi r, Col unbi a Ri ver. Transacti ons of the Aneri can Fi sheri es Soci ety 120: 421- 438.

Vi neyard, G. L. and WJ. O Bri en. 1976. Effects of I i ght and turbi di ty on the reacti ve di stance of bl uegi II (Lepom s macrochi rus). J. Fi sh.

Res. Board Can. 33: 2845- 2849.

Zaret, T. M 1979. Predati on i n freshuater fi sh commini ti es. pages 135-143 in H Clepper, editor. Predator-prey systens in fi sheries managenent. Sport Fi shi ng Institute, Whshi ngt on, Di st ri ct of Col unbi a, USA 
APPEND X A

1990 Revi sed Consumpti on Index Resul ts 
Tabl e A I. Revi sed (i.e. wi thout "gorp"; see Petersen et al 1990 for expl anati on) northern squauf $\mathrm{i}$ sh consumpt $i$ on i ndi ces (CI) at I ocat i ons i n the I ower Col unbi a and Snake Ri vers duri ng 1990. Note that a si ngl e 0 neans no j uveni l e sal moni ds were found in the predat or guts. CI is the consumpti on i ndex for the ori gi nal sample ( $\mathrm{N}$ ). Mean CI, st andard devi ati on (SD), coeffici ent of vari ation $(\mathrm{CV}, \%$ and quartiles are gi ven for the 500 bootstrap

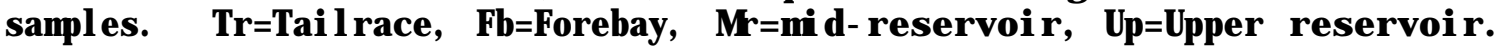

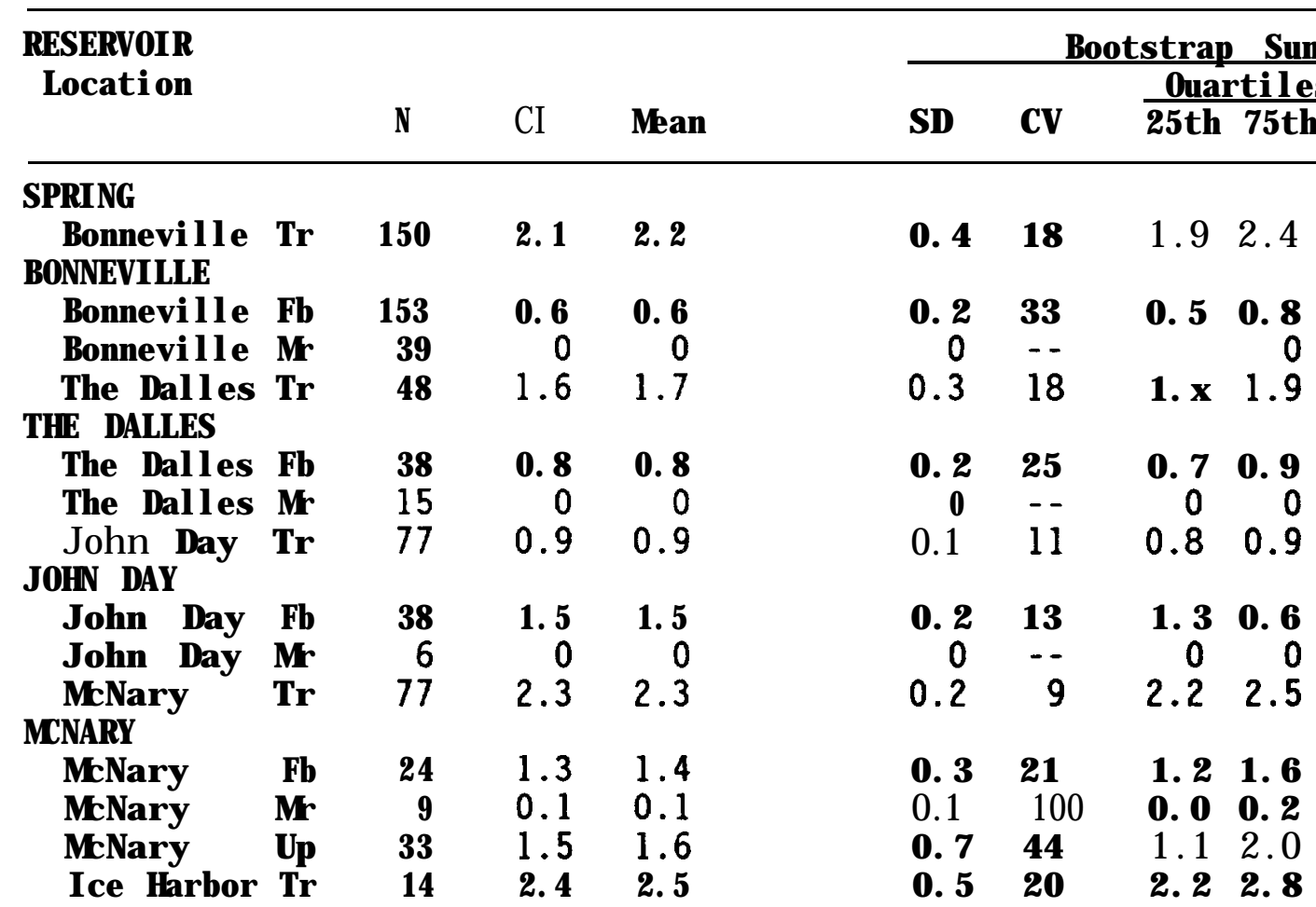

SUMMER

\begin{tabular}{|c|c|c|c|c|c|c|c|c|}
\hline $\begin{array}{l}\text { Bonnevi I I e } \\
\text { BONNEY LLE }\end{array}$ & Tr & 154 & 4. 7 & 4. 8 & 1.0 & 21 & 4. 1 & 5. 4 \\
\hline Bonnevi I I e & $\mathbf{F b}$ & 139 & 1.8 & 1.8 & 0.7 & 39 & 1. 3 & 2. 2 \\
\hline Bonnevi I I e & $\mathbf{M}$ & 42 & 0 & 0 & 0 & & & \\
\hline $\begin{array}{l}\text { The Dal I es } \\
\text { THE DALLES }\end{array}$ & $\mathrm{Tr}$ & 67 & 0.7 & 0.7 & 0.4 & 57 & 0.5 & 0.9 \\
\hline The Dal I es & $\mathbf{F b}$ & 61 & 1.0 & 1.0 & 0.5 & 50 & 0.6 & 1. 4 \\
\hline The Dal I es & $\mathbf{M}$ & 51 & 0.1 & 1.0 & 1.1 & 110 & 0.0 & 6 \\
\hline $\begin{array}{l}\text { J Ohn Day } \\
\text { OHN DAY }\end{array}$ & Tr & 96 & 4. 3 & 4. 3 & 0.7 & 16 & & 4. 8 \\
\hline John Day & $\mathbf{F b}$ & 16 & 2. 4 & 3.2 & 2.4 & 75 & 1. 3 & 4. 8 \\
\hline J ohn Day & $\mathbf{M}$ & 7 & 0.9 & 1.1 & 1.1 & 100 & 0.0 & 1. 6 \\
\hline MeNary & Tr & 75 & 8.0 & 8.2 & 1.4 & 17 & 7. 2 & 9.1 \\
\hline MCNARY & & & & & & & & \\
\hline $\begin{array}{l}\text { MtNary } \\
\text { MtNary }\end{array}$ & $\begin{array}{l}\mathbf{F b} \\
\mathbf{M}\end{array}$ & $\begin{array}{r}9 \\
14\end{array}$ & $\begin{array}{l}2.4 \\
1.8\end{array}$ & $\begin{array}{l}2.5 \\
1.9\end{array}$ & $\begin{array}{l}1.3 \\
0.9\end{array}$ & $\begin{array}{r}52 \\
47\end{array}$ & $\begin{array}{l}1.6 \\
1.2\end{array}$ & $\begin{array}{l}3.4 \\
2.4\end{array}$ \\
\hline MeNary & Up & 36 & 1.5 & 1.6 & 0.5 & 31 & 1.2 & 1.9 \\
\hline Ice Harbor & Tr & 112 & 0.6 & 0.7 & 0.4 & 57 & 0.3 & 0.9 \\
\hline
\end{tabular}


Tabl e A 2. Revi sed Consumpti on i ndi ces ( $\mathrm{a}$ ) of northern squauf i sh wi thi $\mathbf{n}$ dam BRZs in the I ower Col unbi a and Snake Ri vers during 1990. See Table Al for expl anati on of col ums.

\begin{tabular}{|c|c|c|c|c|c|c|c|}
\hline \multirow{2}{*}{$\begin{array}{l}\text { RESERVO R } \\
\text { Locat i on } \\
\text { ( BRZ onl } y \text { ) }\end{array}$} & \multirow[b]{2}{*}{$\mathbf{N}$} & \multirow[b]{2}{*}{ CI } & \multirow[b]{2}{*}{ Mean } & & \multicolumn{3}{|c|}{ Bootstrap Summarv } \\
\hline & & & & SD & $\mathbf{C V}$ & $\frac{\text { Oual }}{25 t h}$ & $\frac{\text { tiles }}{75 t h}$ \\
\hline \multicolumn{8}{|l|}{ SPR NG } \\
\hline $\begin{array}{l}\text { Bonnevi I I e } \mathrm{Tr} \\
\text { BONNEV LLE }\end{array}$ & 89 & 2.2 & 2.7 & 0.3 & 11 & 2.4 & 2.9 \\
\hline $\begin{array}{l}\text { Bonnevi I l e Fb } \\
\text { The Dal I es Tr } \\
\text { THE DALLES }\end{array}$ & $\begin{array}{r}102 \\
41\end{array}$ & $\begin{array}{l}0.9 \\
2.3\end{array}$ & $\begin{array}{l}0.9 \\
2.4\end{array}$ & $\begin{array}{l}0.2 \\
0.3\end{array}$ & $\begin{array}{r}22 \\
12\end{array}$ & $\begin{array}{l}0.8 \\
2.2\end{array}$ & $\begin{array}{l}1.1 \\
2.6\end{array}$ \\
\hline $\begin{array}{l}\text { The Dal les Fb } \\
\text { J Ohn Day Tr } \\
\text { J OHN DAY }\end{array}$ & $\begin{array}{l}21 \\
50\end{array}$ & $\begin{array}{l}1.2 \\
0.9\end{array}$ & $\begin{array}{l}1.2 \\
0.9\end{array}$ & $\begin{array}{l}0.3 \\
0.1\end{array}$ & $\begin{array}{r}25 \\
11\end{array}$ & $\begin{array}{l}1.0 \\
0.8\end{array}$ & $\begin{array}{l}1.4 \\
1.0\end{array}$ \\
\hline $\begin{array}{l}\text { John Day } \\
\text { MENary } \\
\text { MCNARY }\end{array}$ & $\begin{array}{l}34 \\
60\end{array}$ & $\begin{array}{l}1.5 \\
2.5\end{array}$ & $\begin{array}{r}1.5 \\
2.5\end{array}$ & $\begin{array}{l}0.2 \\
0.2\end{array}$ & $\begin{array}{r}13 \\
8\end{array}$ & $\begin{array}{l}1.3 \\
2.4\end{array}$ & $\begin{array}{l}1.6 \\
2.6\end{array}$ \\
\hline $\begin{array}{ll}\text { MeNary } & \text { Fb } \\
\text { I ce Harbor } & \mathrm{Tr}\end{array}$ & $\begin{array}{l}17 \\
14\end{array}$ & $\begin{array}{l}1.6 \\
2.4\end{array}$ & $\begin{array}{l}1.7 \\
2.4\end{array}$ & $\begin{array}{l}0.3 \\
0.5\end{array}$ & $\begin{array}{l}18 \\
21\end{array}$ & $\begin{array}{l}1.4 \\
2.1\end{array}$ & $\begin{array}{l}1.9 \\
2.7\end{array}$ \\
\hline \multicolumn{8}{|l|}{ SUMMER } \\
\hline $\begin{array}{l}\text { Bonnevi I l e Tr } \\
\text { BONNEV LLE }\end{array}$ & 109 & 5.5 & 5.4 & 1.1 & 20 & 4.7 & 6.1 \\
\hline $\begin{array}{l}\text { Bonnevi I l e } \mathrm{Fb} \\
\text { The Dal I es } \\
\text { TrE DALLES }\end{array}$ & $\begin{array}{l}89 \\
63\end{array}$ & $\begin{array}{l}2.4 \\
0.8\end{array}$ & $\begin{array}{l}2.3 \\
0.9\end{array}$ & $\begin{array}{l}0.7 \\
0.5\end{array}$ & $\begin{array}{l}30 \\
55\end{array}$ & $\begin{array}{l}1.9 \\
0.5\end{array}$ & $\begin{array}{l}2.8 \\
1.1\end{array}$ \\
\hline $\begin{array}{l}\text { The Dal I es Fb } \\
\text { John Day Tr } \\
\text { J OHN DAY }\end{array}$ & $\begin{array}{l}25 \\
50\end{array}$ & $\begin{array}{l}3.1 \\
6.4\end{array}$ & $\begin{array}{l}3.2 \\
6.5\end{array}$ & $\begin{array}{l}1.4 \\
0.6\end{array}$ & $\begin{array}{r}44 \\
9\end{array}$ & $\begin{array}{l}2.2 \\
6.0\end{array}$ & $\begin{array}{l}4.1 \\
6.9\end{array}$ \\
\hline $\begin{array}{ll}\text { John Day } & \text { Fb } \\
\text { MENary } & \text { Tr } \\
\text { MeNary } & \text { Fb } \\
\text { I ce Harbor Tr }\end{array}$ & $\begin{array}{r}11 \\
50 \\
8 \\
79\end{array}$ & $\begin{array}{r}2.9 \\
11.7 \\
2.5 \\
0.9\end{array}$ & $\begin{array}{r}4.0 \\
11.8 \\
2.6 \\
1.0\end{array}$ & $\begin{array}{l}3.2 \\
1.0 \\
1.3 \\
0.5\end{array}$ & $\begin{array}{r}80 \\
8 \\
50 \\
50\end{array}$ & $\begin{array}{r}1.6 \\
11.2 \\
1.7 \\
0.6\end{array}$ & $\begin{array}{r}5.8 \\
12.6 \\
3.3 \\
1.3\end{array}$ \\
\hline
\end{tabular}


Tabl e A 3. Revi sed Reservoi $r$ - wi de (excl udi ng BRZs at dans) Cls of northern squauf i sh duri ng 1990 sampl i ng in the I ower Col unbi a and Snake Ri vers. See Table Al for expl anation of col ums.

\begin{tabular}{|c|c|c|c|c|c|c|c|}
\hline \multirow{2}{*}{$\begin{array}{c}\text { RESERVO R } \\
\text { (excluding } \\
\text { BRZ's ) }\end{array}$} & \multirow[b]{2}{*}{$\mathbf{N}$} & \multirow[b]{2}{*}{$\mathrm{CI}$} & \multirow[b]{2}{*}{ Mean } & \multicolumn{4}{|c|}{ Bootstrap Summer } \\
\hline & & & & SD & $\mathbf{C V}$ & $\frac{\text { Quar }}{25 \text { th }}$ & $\frac{\text { rtiles }}{75 \text { th }}$ \\
\hline \multicolumn{8}{|l|}{ SPR NG } \\
\hline $\begin{array}{l}\text { BONNEY LLE } \\
\text { THE DALLES } \\
\text { J OHN DAY } \\
\text { MCNARY }\end{array}$ & $\begin{array}{l}58 \\
27 \\
49\end{array}$ & $\begin{array}{l}0.0 \\
04 \\
1.3 \\
1.0\end{array}$ & $\begin{array}{l}0.1 \\
0.4 \\
1.4 \\
1.0\end{array}$ & $\begin{array}{l}0.1 \\
0.1 \\
0.4 \\
0.4\end{array}$ & $\begin{array}{l}86 \\
36 \\
27 \\
38\end{array}$ & $\begin{array}{l}0.0 \\
0.3 \\
1.1 \\
0.7\end{array}$ & $\begin{array}{l}0.1 \\
0.5 \\
1.6 \\
1.3\end{array}$ \\
\hline \multicolumn{8}{|l|}{ SUMMER } \\
\hline $\begin{array}{l}\text { BONNEV LLE } \\
\text { THE DALLES } \\
\text { J OHN DAY } \\
\text { MCNARY }\end{array}$ & $\begin{array}{r}96 \\
133 \\
37 \\
84\end{array}$ & $\begin{array}{l}\quad \mathbf{0}^{-} \\
0.1 \\
2.2 \\
1.2\end{array}$ & $\begin{array}{l}\mathbf{0} \\
0.1 \\
2.3 \\
1.2\end{array}$ & $\begin{array}{l}0 \\
0.1 \\
1.2 \\
0.4\end{array}$ & $\begin{array}{c}- \\
100 \\
3352\end{array}$ & $\begin{array}{r}\mathbf{0} \\
0.2 \\
\\
1.41 .0\end{array}$ & $\begin{array}{r}\mathbf{0} \\
0.2\end{array}$ \\
\hline
\end{tabular}

